2020-10-14

\title{
A review of a decade of lessons from one of the world's largest MPAs: conservation gains and key challenges
}

\author{
Hays, GC
}

http://hdl.handle.net/10026.1/16439

\subsection{7/s00227-020-03776-w}

Marine Biology

Springer Science and Business Media LLC

All content in PEARL is protected by copyright law. Author manuscripts are made available in accordance with publisher policies. Please cite only the published version using the details provided on the item record or document. In the absence of an open licence (e.g. Creative Commons), permissions for further reuse of content should be sought from the publisher or author. 
1 A review of a decade of lessons from one of the world's largest MPAs:

Graeme C. Hays ${ }^{1 *}$, Heather J. Koldewey ${ }^{2,3}$, Jessica J. Meeuwig ${ }^{4}$, Samantha Andrzejaczek ${ }^{5}$, Martin J. Attrill $^{6}$, Shanta Barley ${ }^{7,8}$, Daniel T.I. Bayley ${ }^{9}$, Cassandra E. Benkwitt ${ }^{10}$, Barbara Block ${ }^{5}$, Robert J. Schallert $^{5}$, Aaron B. Carlisle ${ }^{11}$, Pete Carr ${ }^{3,12}$, Taylor K. Chapple ${ }^{13}$, Claire Collins ${ }^{3,12}$, Clara Diaz ${ }^{6}$, Nicholas Dunn ${ }^{12,14}$, Robert B. Dunbar ${ }^{15}$, Dannielle S. Eager ${ }^{6}$, Julian Engel ${ }^{16}$, Clare B. Embling 6 , Nicole Esteban ${ }^{17}$, Francesco Ferretti ${ }^{18}$, Nicola L. Foster ${ }^{6}$, Robin Freeman ${ }^{12}$, Matthew Gollock ${ }^{2}$, Nicholas A.J. Graham ${ }^{10}$, Joanna L. Harris ${ }^{6,19}$, Catherine E.I. Head ${ }^{12,20}$, Phil Hosegood ${ }^{6}$, Kerry L. Howell $^{6}$, Nigel E. Hussey ${ }^{21}$, David M.P. Jacoby ${ }^{12}$, Rachel Jones ${ }^{2}$, Ines D. Lange ${ }^{22}$, Tom B.

Letessier $^{4,12}$, Emma Levy ${ }^{2}$, Mathilde Lindhart ${ }^{23}$, Jamie M. McDevitt-Irwin ${ }^{5}$, Mark Meekan ${ }^{24}$, Fiorenza Micheli ${ }^{5,25}$, Andrew Mogg ${ }^{26,27}$, Jeanne A. Mortimer ${ }^{28,29}$, David A. Mucciarone ${ }^{15}$, Malcolm A. Nicoll ${ }^{12}$, Ana Nuno ${ }^{3,30}$, Chris T. Perry ${ }^{22}$, Sivajyodee Sannassy Pilly ${ }^{31}$, Stephen G. Preston ${ }^{20}$, Alex J. Rattray ${ }^{1}$, Edward Robinson ${ }^{6}$, Ronan C. Roche ${ }^{31}$, Melissa Schiele ${ }^{12}$, Emma V. Sheehan ${ }^{6}$, Anne Sheppard ${ }^{31,32}$, Charles Sheppard ${ }^{31,32}$, Adrian L. Smith ${ }^{20}$, Bradley Soule ${ }^{16}$, Mark Spalding ${ }^{33}$, Guy M.W. Stevens ${ }^{19}$, Margaux Steyaert ${ }^{12,20}$, Sarah Stiffel ${ }^{20}$, Brett M. Taylor ${ }^{25}$, David Tickler ${ }^{8}$, Alice M. Trevail $^{34}$, Pablo Trueba ${ }^{16}$, John Turner ${ }^{31}$, Stephen Votier ${ }^{34}$, Bry Wilson ${ }^{20}$, Gareth J. Williams ${ }^{31}$, Benjamin J. Williamson ${ }^{35}$, Michael J. Williamson ${ }^{12,36}$, Hannah Wood ${ }^{12}$, David J. Curnick ${ }^{12}$

*Correspondence g.hays@deakin.edu.au

${ }^{1}$ Deakin University, Centre for Integrative Ecology, Geelong, Australia

${ }^{2}$ Zoological Society of London, Regent's Park, London NW1 4RY, UK

${ }^{3}$ Centre for Ecology and Conservation, College of Life and Environmental Sciences, University of Exeter, Penryn, Cornwall TR10 9FE, UK

${ }^{4}$ School of Biological Sciences (M092), The University of Western Australia, Crawley, WA, 6009, Australia

${ }^{5}$ Hopkins Marine Station, Stanford University, Pacific Grove, CA, USA

${ }^{6}$ School of Biological and Marine Sciences, University of Plymouth, Plymouth, PL4 8AA, UK

${ }^{7}$ Minderoo Foundation, 80 Birdwood Parade, Western Australia, 6009

${ }^{8}$ School of Biological Sciences, The University of Western Australia, Crawley, Western Australia, 6009

${ }^{9}$ Centre for Biodiversity and Environment Research, University College London, Bloomsbury, London WC1H 0AG

${ }^{10}$ Lancaster Environment Centre, Lancaster University, Lancaster, LA1 4YQ, UK

${ }^{11}$ School of Marine Science and Policy, University of Delaware, Lewes, DE, 19958, USA

${ }^{12}$ Institute of Zoology, Zoological Society of London, Regent's Park, London NW1 4RY, UK

${ }^{13}$ Hatfield Marine Science Center, Oregon State University, 2030 SE Marine Science Drive Newport, OR 97365, USA

${ }^{14}$ Department of Life Sciences, Imperial College London, Silwood Park, Ascot, UK

${ }^{15}$ Earth System Science, Stanford University, Stanford CA 94305

${ }^{16}$ OceanMind Limited, Harwell Innovation Centre, Building 173 Curie Avenue, Harwell, Didcot OX11 0QG

${ }^{17}$ Department of Biosciences, Swansea University, Swansea SA2 8PP, Wales, UK

${ }^{18}$ Department of Fish and Wildlife Conservation, College of Natural Resources and Environment, Virginia Tech, Blacksburg, VA, USA

${ }^{19}$ The Manta Trust, Catemwood House, Norwood Lane, Corscombe, Dorset, DT2 0NT, UK

${ }^{20}$ Department of Zoology, University of Oxford, Oxford OX1 3SZ, UK 
${ }^{21}$ Department of Integrative Biology, University of Windsor, Ontario, N9B 3P4.Canada. ${ }^{22}$ Geography, College of Life and Environmental Sciences, University of Exeter, Exeter, EX4 4RJ, UK

${ }^{23}$ Civil and Environmental Engineering, Stanford University, Stanford CA 94305

${ }^{24}$ Australian Institute of Marine Science, Indian Ocean Marine Research Centre, The University of Western Australia, Crawley, 6009, Western Australia, Australia

${ }^{25}$ Center for Ocean Solutions, Stanford University, 120 Ocean View Blvd, Pacific Grove, CA 93950, USA

${ }^{26}$ NERC National Facility for Scientific Diving, Scottish Association for Marine Science, Oban, UK

${ }^{27}$ Tritonia Scientific Ltd., Dunstaffnage Marine Laboratories, Oban, UK, PA37 1QA

${ }^{28}$ Department of Biology, University of Florida, Gainesville, Florida 32611, USA

${ }^{29}$ P.O. Box 1443, Victoria, Mahé, Seychelles

${ }^{30}$ Interdisciplinary Centre of Social Sciences (CICS.NOVA), School of Social Sciences and Humanities (NOVA FCSH), NOVA University Lisbon, Avenida de Berna, 26-C, 1069-061 Lisboa, Portugal

${ }^{31}$ School of Ocean Sciences, Bangor University, Menai Bridge, Wales UK, LL59 5AB

${ }^{32}$ School of Life Sciences, University of Warwick, Coventry, CV4 7AL, UK

${ }^{33}$ Conservation Science Group, Department of Zoology, University of Cambridge, Cambridge, CB2 3QZ, UK

${ }^{34}$ Environment and Sustainability Institute, University of Exeter, Penryn Campus, Penryn, Cornwall, TR10 9FE, UK

${ }^{35}$ Environmental Research Institute, University of the Highlands and Islands, Ormlie Road, Thurso, KW14 7EE, UK

${ }^{36}$ Department of Geography, King's College London, London, WC2B 4BG, UK

\begin{abstract}
Given the recent trend towards establishing very large marine protected areas (MPAs) and the high potential of these to contribute to global conservation targets, we review outcomes of the last decade of marine conservation research in the British Indian Ocean Territory (BIOT), one of the largest MPAs in the world. The BIOT MPA consists of the atolls of the Chagos Archipelago, interspersed with, and surrounded by, deep oceanic waters. Islands around the atoll rims serve as nesting grounds for sea birds. Extensive and diverse shallow and mesophotic reef habitats provide essential habitat and feeding grounds for all marine life, and the absence of local human impacts may improve recovery after coral bleaching events. Census data have shown recent increases in the abundance of sea turtles, high numbers of nesting seabirds and high fish abundance, at least some of which is linked to the lack of recent harvesting. For example, across the archipelago the annual number of green turtle nests (Chelonia mydas) is $\sim 20,500$ and increasing and the number of seabirds is $\sim 1$ million. Animal tracking studies have shown that some taxa breed and/or forage consistently within the MPA (e.g. some reef fishes, elasmobranchs and seabirds), suggesting the MPA has the potential to provide long-term protection. In contrast, post-nesting green turtles travel up to $4000 \mathrm{~km}$ to distant foraging sites, so the protected beaches in the Chagos Archipelago provide a nesting sanctuary for individuals that forage across an ocean basin and several geopolitical borders. Surveys using divers and underwater video systems show high habitat diversity and abundant marine life on all trophic levels. For example, coral cover can be as high as 40-50\%. Ecological studies are shedding light on how remote ecosystems function, connect to each other and respond to climate-driven stressors compared to other locations that are more locally impacted. However, important threats to this MPA have been identified, particularly global heating events, and Illegal, Unreported and Unregulated (IUU) fishing activity, which considerably impact both reef and pelagic fishes.
\end{abstract}


100

101

102

103

104

105

106

107

108

109

110

111

112

113

114

115

116

117

118

119

120

121

122

123

124

125

126

127

128

129

130

131

132

133

134

135

136

137

138

139

140

141

142

143

144

145

146

147

148

149

Keywords: VLMPA, biologging, conservation, marine megafauna, shark, coral reefs, Aichi targets, seamounts

\section{Introduction}

The growing recognition that marine ecosystems are threatened by biodiversity declines and habitat degradation (McCauley et al. 2015) has led to international calls for protecting the world's ocean, including within Marine Protected Areas (MPAs) (Convention on Biological Diversity's Aichi Target $11 \mathrm{https}: / / \mathrm{www} . c b d . i n t / s p / t a r g e t s /$ Woodley et al. 2019). Negotiations at the United Nations are also ongoing to establish a new international treaty within which MPAs would be established in Areas Beyond National Jurisdiction (ABNJs) (O'Leary et al. 2020). A large body of research spanning over 50 years demonstrates that in general, MPAs lead to increases in biodiversity, abundance, size and biomass (e.g. Ballantine 2014; Lester et al. 2009). Importantly, there is also clear evidence of fisheries benefits (Goñi et al. 2010; Harrison et al. 2012), well-being and social benefits (Ban et al. 2019), and resilience afforded by protection in the face of climate change (Mellin et al. 2016; Roberts et al. 2017). While there are recognised limitations (Devillers et al. 2015; Edgar et al. 2014; Giakoumi et al. 2018), impacts of protection are largely positive in coastal ecosystems.

Very Large Marine Protected Areas (VLMPAs), areas $>100,000 \mathrm{~km}^{2}$, are fundamental to halting and reversing ocean health declines and to meeting global targets. The Aichi Target calls for a minimum of $10 \%$ of the world's ocean to be protected by 2020 , a target that will not be met with currently only $2.5 \%$ of the ocean's surface in highly protected MPAs (http://www.mpatlas.org/; Sala et al. 2018). Additionally, the 30x30 initiative, supported by the analysis of O'Leary et al. (2016), suggests that a minimum of $30 \%$ of the ocean should be in highly protected MPAs. Positive conservation outcomes from large-scale protection are also expected to generate positive social, economic and equity outcomes with respect to food security and resource access (Sumaila et al. 2015). However, the benefits of VLMPAs remain debated and empirical studies evaluating their effectiveness are essential. These studies have been limited due to the relatively young age of VLMPAs; the first VLMPA to be established was the Pacific Remote Islands National Marine Monument in 2009 (MPA Atlas, http://mpatlas.org/mpa/sites/7704395/). Significant challenge also exists in delivering conservation research in remote regions and on large spatial scales that include offshore pelagic environments.

The British Indian Ocean Territory (BIOT) MPA was proclaimed by the UK Government in April 2010. It is classified as a VLMPA at $640,000 \mathrm{~km}^{2}$ and as an IUCN management category 1a strict nature reserve (Day et al. 2019), with effectively no permitted fishing. At the time of its designation, it was the largest contiguous highly protected MPA. The MPA includes a range of habitats with deep oceanic areas surrounding the shallow reef environments and reef islands of the Chagos Archipelago. Its recognition as an important site for conservation (reviewed previously by Sheppard et al. 2012) has helped drive a concerted programme of ongoing studies to understand the outcomes of the MPA's creation and its importance for the species and ecosystems it hosts. At the same time, the legality of this MPA has been challenged (Appleby 2015; United Nations 2019). Given both the ongoing challenges to the BIOT MPA and the wealth of recent studies, here we assess the knowledge gains over the past decade regarding this MPA's conservation value. We also discuss the ongoing conservation challenges facing the BIOT MPA that continue to require new and innovative approaches and consider the implications of the lessons learnt for marine conservation planning and management more broadly across the globe. 


\section{Materials and methods}

151

\section{2}

153

154

155

156

157

158

159

160

161

162

163

164

165

166

167

168

169

170

171

172

173

174

175

176

177

178

179

180

181

182

183

184

185

186 187

\section{Identifying Case Studies}

Marine research in BIOT extends back to the 1970s but has increased rapidly in the last 15 years. Recently, much of the research within the BIOT MPA has been coordinated through the Bertarelli Programme in Marine Science (BPMS). At the annual BPMS meeting in London (18-20 September 2019), programme-supported scientists were asked to describe their key recent findings that highlight either the conservation value or the challenges facing the MPA. Experts who attended this meeting were also asked to identify other individuals from around the world who should be invited to participate in writing a review summarizing the last decade of research on the BIOT MPA. The assembled authors were able to provide comprehensive coverage of the breadth of recent work that has taken place concerning the BIOT MPA, including work on a range of habitats including shallow coral reefs and pelagic realms as well as a range of taxa including fishes, seabirds and turtles. Case studies were identified by taxonomic group, by habitat, or by ecological question and then experts in each area prepared text describing their recent discoveries, which are synthesised below.

\section{Background and overview of recent scientific work}

Of the $640,000 \mathrm{~km}^{2}$ of the BIOT MPA, $19,120 \mathrm{~km}^{2}$ is shallower than $100 \mathrm{~m}$ and the remainder is deep oceanic water with maximum depths of $>5,000 \mathrm{~m}$. The Chagos Archipelago consists of discrete atolls with around 58 associated islands, submerged banks, and an estimated 86 seamounts. The Great Chagos Bank is described as the world's largest atoll structure, covering an area of 12,642 km and water depths down to about $90 \mathrm{~m}$ (Fig. 1). The land area of the islands within the archipelago totals only $56 \mathrm{~km}^{2}$. These islands are surrounded by shallow fringing coral reefs and encompass lagoons with sheltered reefs, patch reefs, coral outcrops and seagrass meadows. The BIOT MPA covers the entire Economic Exclusion Zone (EEZ) with the exception of Diego Garcia atoll and a three-nautical mile buffer around it, noting that large parts of this atoll and waters receive separate protection under multiple legal and other regulatory controls (https://biot.gov.io/). From the $18^{\text {th }}$ century until the 1970s, the archipelago was managed as a coconut oil plantation. When the final plantations closed, the archipelago was declared a military exclusion area, and the remaining population was relocated (Wenban-Smith and Carter 2017). Since then, commercial fishing, comprising licensed pelagic longline and purse seine fisheries and a relatively small-scale demersal fishery, was allowed up until 2010 at which point all legal commercial fishing ceased. Local human impacts on the reefs within the MPA have generally been minimal, but were significant on the islands when previously settled. Approximately half of Diego Garcia, which has the only current human settlement in the archipelago, has been extensively altered for the creation of a large military facility, with buildings and infrastructure, including coastal modification, ports and anchorages. 


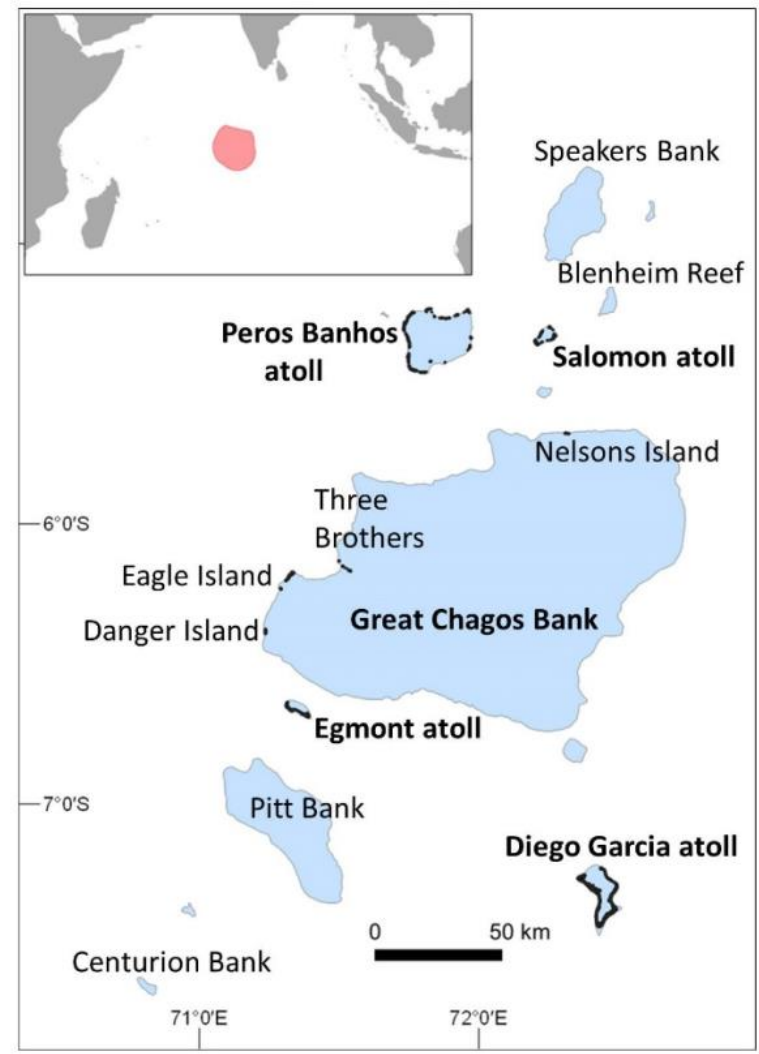

Fig. 1 The Chagos Archipelago. Inset shows the general location within the Indian Ocean and the MPA boundary (red). Main map shows the archipelago which lies at the heart of the MPA. The five atolls with land are in bold, versus selected submerged reefs and atolls not in bold. Islands on the Great Chagos Bank include Danger Island, Eagle Island, Three Brothers Islands and Nelsons Island. Blue shading indicates water shallower than approximately $100 \mathrm{~m}$.

The isolated and protected nature of the Chagos Archipelago means that many human influences are minimal. This limited human presence and remote setting of the BIOT MPA provides a baseline to compare with other systems more impacted by anthropogenic pressures. All else being equal, it might be expected that the MPA would result in positive species and habitat conservation outcomes. There have been considerable recent efforts, documented below, to quantify species abundances for comparison with other areas in the Indian Ocean, as well as assessing long-term changes within the archipelago. This work has shown the value of the MPA for sea turtles, pelagic and reef-associated fishes, seabirds, invertebrates and key habitats, such as coral reefs and seagrass beds (Fig. 2). To assess patterns of movement in relation to the MPA, a range of turtles, fishes and seabirds have been tracked using satellite (Argos and GPS), acoustic telemetry and archival biologging packages. Coral reef surveys have been conducted for four decades, informing research on how climate change impacts these ecosystems. Fish surveys on reefs and in pelagic areas with stereo Baited Remote Underwater Video Systems (BRUVS) have been used to describe species assemblages and relative abundance. More recently, detailed oceanographic studies have been undertaken to better understand the drivers behind the biotic patterns and behaviours observed, while remotely operated vehicles (ROVs) have been employed to study the health and diversity of mesophotic reefs and how they may act as refuges for shallow reefs. The temporal, spatial and bathymetric extent of data is thus now significant and increasing rapidly. In addition to these studies on abundance, trends and movements, the MPA has allowed a range of questions to be addressed on ecosystem functioning, movement ecology and animal behaviour in an environment relatively free of most human influences. At the 
same time, patrols of the MPA provide indications of the extent of Illegal, Unreported and

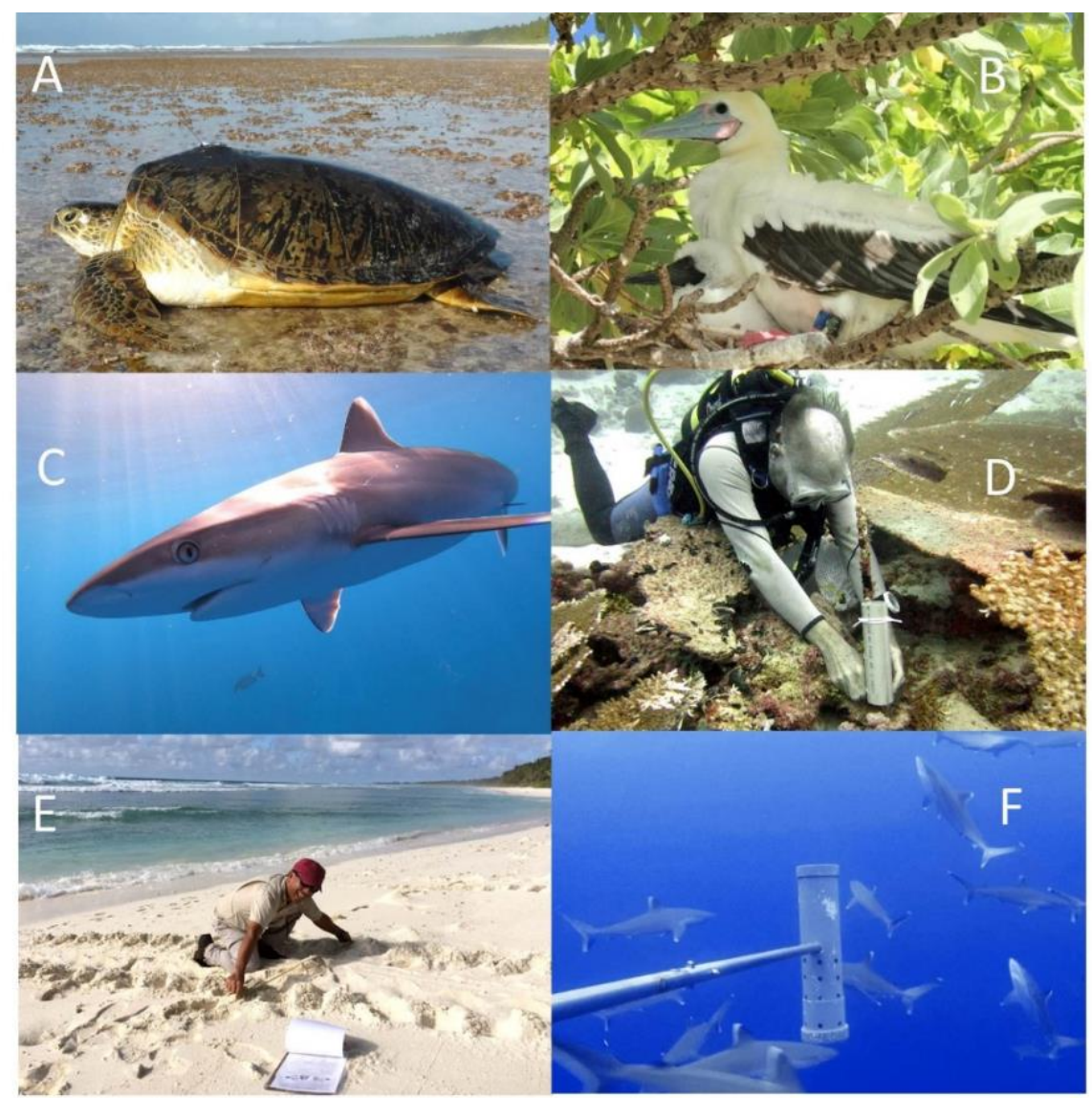

Fig. 2 The breadth of recent studies in the BIOT MPA. Recent work in the BIOT MPA has used electronic tags to track the movements of sea turtles, seabirds and fish. Pictured with tags attached a a green turtle (Chelonia mydas) with a Fastloc-GPS Argos tag on the carapace, $\mathbf{b}$ a red-footed booby (Sula sula) with a light-based geolocator tag on its leg, $\mathbf{c}$ a silvertip shark (Carcharhinus albimarginatus) prior to being fitted with a long-term, internal acoustic transmitter. d Habitat surveys using SCUBA and deployed instruments have shown long-term changes in reef environments and water temperature. e Counting tracks on beaches has revealed long-term increases in sea turtle nesting numbers. f Marine surveys have been extended using technology such as Baited Remote Underwater Video Systems (BRUVS) deployed in the open ocean or in shallow coastal areas. Pictured in (f) silvertip sharks. Images courtesy (a,e) Nicole Esteban and Graeme Hays, (b) Hannah Wood, (c) David Curnick, (d) Charles Sheppard, (f) Jessica Meeuwig.

\section{Review structure}

We begin by examining the importance of the BIOT MPA for coral reefs and coral reef research. We then consider work with taxa that has included tracking individuals and/or census surveys including coral reef fish, turtles, seabirds and pelagic fish. We then consider recent knowledge gains regarding invertebrate fauna and mesophotic reefs. We examine how the MPA has provided an environment for seminal work on natural behaviours and ecological relationships in the absence of anthropogenic influences and we consider how the physical oceanography of the region may influence its ecological 
value. Finally, we highlight the key threats the MPA faces, particularly climate warming impacts on coral reefs and IUU fishing impacts on fish stocks.

\section{Results}

\section{Importance of the BIOT MPA for coral reefs and coral reef research}

The BIOT MPA represents a valuable reference site for understanding coral community resilience in an ocean where most reefs have undergone significant and continuing declines in health. Although reefs in the Chagos Archipelago have not been spared from the effects of large climate driven stressors (i.e. temperature-driven coral bleaching), the MPA has afforded protection from many of the local threats that reefs face in other parts of the world such as destructive fishing practices, local pollution, or sedimentation and eutrophication from anthropogenic land-based sources.

Data collected following the major coral bleaching event of 1998 showed that despite its geographically isolated position, the Chagos Archipelago was not immune from widespread coral mortality, which extended to depths of $>40 \mathrm{~m}$ in some locations (Sheppard et al. 2012). However, most of the reefs recovered quickly and by 2012 coral cover on reefs in the BIOT MPA averaged 40$50 \%$ (Fig. 3a,d), with juvenile coral densities of 20-60 colonies $\mathrm{m}^{-2}$ (Fig. 3b) (Sheppard et al. 2017; Sheppard and Sheppard 2019). Thus, the reefs had largely regained coral cover levels consistent with those documented prior to 1998 and coral recruitment was clearly prolific. This high coral cover and return of dominant branching and tabular species on many fore reef sites supported high net positive carbonate budgets, an important metric influencing reef growth potential and the maintenance of habitat complexity (Perry et al. 2015). Resultant estimates of average vertical reef accretion rates on Acropora dominated reefs $\left(4.4 \pm 1.0 \mathrm{~mm} \mathrm{yr}^{-1}\right)$ were high in a global context, indicating that many of the reefs would have the capacity to track projected future sea level rise (Perry et al. 2018). For context it is important to note that not all reefs in the wider region recovered as well or as fast after the 1997-1998 bleaching event. For example, shallow reefs in the Maldives recovered to prebleaching states by 2013-2014, albeit comparatively slowly and displaying subtle changes in community composition (e.g. Morri et al. 2015), whilst in the Seychelles reefs followed more divergent recovery trajectories. Some sites recovered well, while others regime-shifted to macroalgal or rubble dominated states with coral cover $<10 \%$ (e.g. Chong-Seng et al. 2014; Harris et al. 2014, Graham et al. 2015). Regime-shifted sites had negative carbonate budgets and shifted to erosional states (Perry et al. 2018).

It is clear that the absence of local impacts, provided by the remoteness of the Chagos Archipelago and the presence of the MPA, aided relatively rapid recovery of many reefs compared to other Indian Ocean sites (Sheppard and Sheppard 2019). In particular, water quality is emerging as an important factor shaping the response of corals and reefs to heat stress (Wooldridge and Done 2009; D'Angelo and Wiedenmann 2014; MacNeil et al. 2019; Lapointe et al. 2019; Donovan et al. 2020). Specifically, an increase in nitrogen (especially nitrate) coupled with phosphorous limitation, which are typical of land-based pollution, exacerbate the effects of heat stress and prolong recovery time following bleaching events (Wiedenmann et al. 2013; Ezzat et al. 2016; Burkepile et al. 2020). The absence of such stressors within the Chagos Archipelago is likely a key contributor to the rapid recovery observed on these reefs compared to other reefs within the region and within other globally important MPAs (e.g., the Florida Keys National Marine Sanctuary and the Great Barrier Reef Marine Park) (MacNeil et al. 2019; Lapointe et al. 2019).

However, it is also relevant to note that these reefs have not been immune from repeated disturbances over the last decade. Localised outbreaks of crown-of-thorns starfish (Acanthaster planci) were observed in 2013, causing high mortality of branching Acropora spp. (Roche et al. 2015). White Syndrome disease was prevalent on many reefs in 2014 and 2015, causing widespread mortality of tabular Acropora colonies (Wright 2016; Sheppard et al. 2017). Most significantly, 
however, the reefs were again heavily impacted by the recent global heat stress event, which caused back-to-back coral bleaching and mortality in 2015 and 2016. Intensive research efforts in BIOT over the last five years are providing detailed insights into subsequent ecological changes across a wide range of depths and habitats.

As after the 1998 event, widespread coral mortality reduced average coral cover to around 10\% in 2017, mainly affecting reefs to a depth of $15 \mathrm{~m}$ (Fig. 3a,e) (Sheppard et al. 2017; Head et al. 2019). This decline in coral cover was driven primarily by a $~ 90 \%$ decline in Acropora spp. cover in shallow and mid depths, shifting community composition from competitive to stress-tolerant taxa and leaving Porites spp. as the dominant coral genus post-bleaching (Head et al. 2019; Lange and Perry 2019). In deeper water (20 m+), the largest losses were of foliacious coral morphologies. No evidence of coral acclimation following 1998 can thus be inferred. Soft corals have also been lost, especially on shallow reefs and seaward facing exposed reefs, and now occupy less than $4 \%$ in the $15-25 \mathrm{~m}$ depth range. Sponges showed an initial increase in 2018, especially in deep waters, but have declined to about 12\% cover in 2019 (Sannassy Pilly et al. unpubl. data). Despite the decrease in coral cover, fleshy macroalgae are very rare, which may be attributed to the absence of nutrient stress from fertilizer and sewage runoff that negatively affects reefs in many coastal areas (Fabricius 2005; Lapointe et al. 2019). The only life form to show a mean increase across reefs are calcifying algae (especially Halimeda spp.), which have increased from negligible values to $12 \%$ in shallow waters and to $15-16 \%$ in deeper waters. Crustose coralline algae cover has increased from $8 \%$ to around $25 \%$ in shallow water and to around 20\% in deeper waters in 2019 (Benkwitt et al. 2019; Sannassy Pilly et al. unpubl. data). From a geo-ecological perspective, the main consequence of the above community changes has been a major decline in carbonate production rates, which have dropped by an average of $77 \%$ (Fig. 3c). At the same time, mean reef rugosity declined by $16 \%$ (Fig. 3c) and rubble cover doubled between 2015 and 2018 (Lange and Perry 2019).

Critical questions at present are whether the reefs will follow the same recovery trajectories as after 1998, or whether more divergent trajectories will occur in different sites and locations (see section below on Key Ongoing Threats). The presence of the BIOT MPA guarantees that recovery trajectories will not be impeded by local stressors such as anthropogenically-derived nitrogen enrichment and altered nutrient ratios, which can exacerbate coral disease and bleaching and have led to reef degradation in other protected areas, e.g. the Florida Keys National Marine Sanctuary (Lapointe et al. 2019). Still, recovery potential will ultimately depend on the recurrence intervals and magnitudes of future heat stress events. 

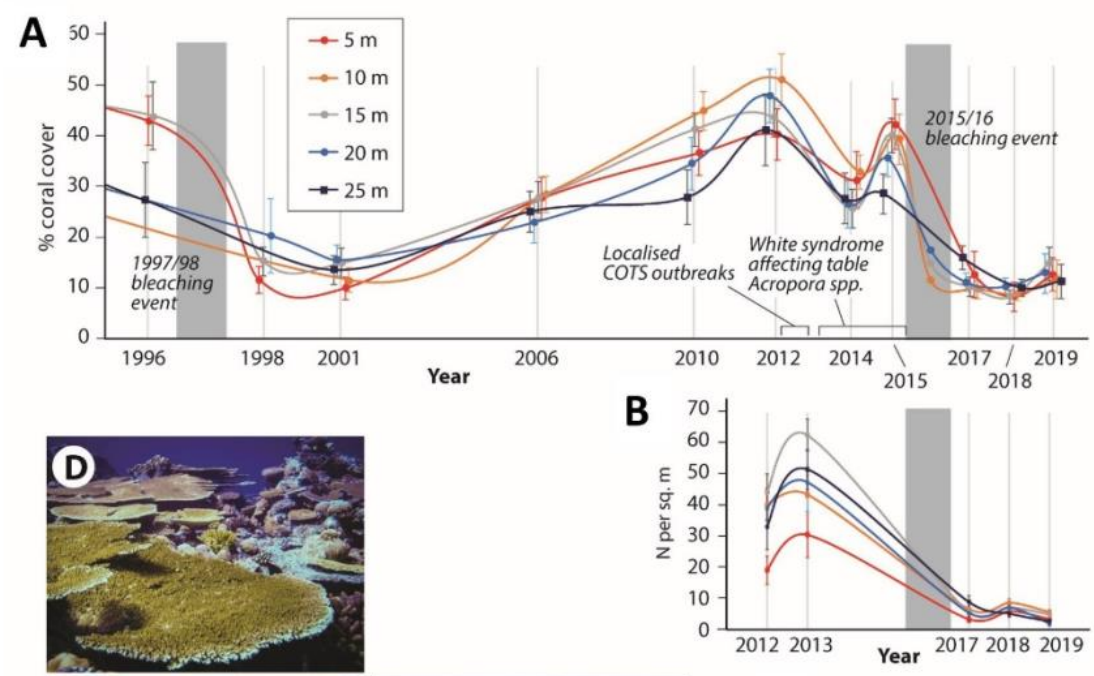

B
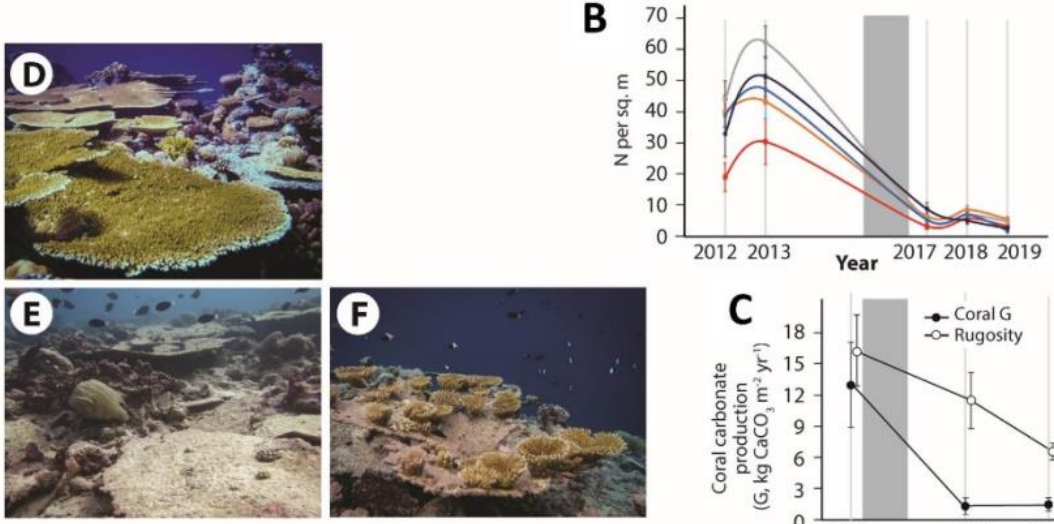

\section{Coral reef fishes are much more abundant than in other Indian Ocean locations}

The first underwater visual surveys of fish biomass and community structure in the Chagos Archipelago were conducted on the outer reef slopes of the atolls in 2010, the year the MPA was established. The archipelago had also been a de facto MPA for reef fishes, with very limited reef fishing since the 1970s (Koldewey et al. 2010). Fish biomass on these reefs was six times greater than even the best-protected smaller MPAs surveyed across eight other countries in the WIO (Graham and McClanahan 2013). Much of this biomass was made up of species targeted by fishing elsewhere in the region, higher trophic level species and larger body-sized fishes (Graham et al. 2013). These species often have large home ranges (Green et al. 2015), making them vulnerable to fishing pressures outside smaller MPAs. The trophic structure of fish communities across the Indian Ocean changes dramatically with fishing pressure (Barley et al. 2017; Barley et al. 2020) and in the Chagos Archipelago forms a concave shape, with biomass accumulating at the top and bottom of the trophic structure, allowing for efficient energy transfer through the food-web (Graham et al. 2017). The semi-pristine fish community allowed for baselines in a range of community-level life history and functional metrics, including maximum length, length at maturity and abundance of top predators and grazers, to be benchmarked across the region (McClanahan and Graham 2015; McClanahan et al. 2015), and regional-level management priorities to be set (McClanahan et al. 2016). 
The high biomass values and relatively intact community structure have also been informative to global fish ecology and fisheries studies. Along with some remote locations in the Pacific, fish biomass and structure in the Chagos Archipelago enabled estimates of unfished biomass for coral reefs globally (MacNeil et al. 2015) and the functional structure of semi-pristine fish communities to be established (D'Agata et al. 2016). Globally, the reef fish biomass in the Chagos Archipelago stands out as a 'bright spot', being greater than would be expected based on the human and environmental conditions experienced alone (Cinner et al. 2016), with indications that deepwater refuges and the natural flow of nutrients may contribute to this high biomass (Graham et al. 2018). Further, the biomass and proportion of reefs with top predators helped identify the key role of distance to markets as a driver of resource condition inside and out of MPAs (Cinner et al. 2018), as has been also observed for pelagic species (Letessier et al. 2019). Reef fish otolith studies in the region have revealed the effects of fishing pressure on life spans and patterns of mortality of fishes in other locations across the Indo-Pacific (Taylor et al. 2019). Biochronological reconstructions of growth histories of fish species have furthermore helped to refine ecological feedback loops between parrotfishes and habitat disturbance (Taylor et al. 2020a) as well as decadal growth responses to oceanographic conditions (Taylor et al. 2020b).

\section{A climate resilient nesting sanctuary for turtles from across the Western Indian Ocean (WIO)} Green (Chelonia mydas) and hawksbill (Eretmochelys imbricata) turtles nest in the Chagos Archipelago with both species heavily exploited for two centuries prior to protection being introduced in 1968-1970, with the creation of the MPA further reinforcing this protection (Mortimer et al. 2020). Ongoing census data have highlighted both regionally important nesting populations as well as upwards trends in abundance. For example, estimates of the annual number of clutches across the archipelago for the period 2011-2018 are 6,300 and 20,500 for hawksbill and green turtles respectively, increasing 2-5 times for hawksbills and 4-9 times for green turtles since 1996 (Mortimer et al. 2020). These upward trends in nesting for both species presumably reflect, at least in part, the fact that there has been no known human exploitation of eggs or adults in the Chagos Archipelago for $~ 50$ years. Regional estimates indicate that the Chagos Archipelago accounts for 39$51 \%$ of hawksbill and 14-20\% of green turtle clutches laid across the entire south-western Indian Ocean (Mortimer et al. 2020).

Satellite tracking of nesting green turtles in the Chagos Archipelago has shown that they disperse widely across the WIO at the end of their nesting season, which peaks during June to October (Fig. 4) (Hays et al. 2020; Mortimer et al. 2020). While some individuals travel to foraging grounds around $80 \mathrm{~km}$ away on the Great Chagos Bank, others travel to foraging grounds 1,000s of $\mathrm{km}$ away, for example, in the Seychelles, Maldives and mainland Africa. The Chagos Archipelago thus provides a key nesting sanctuary for adult green turtles foraging across much of an ocean basin. Ongoing work is assessing migration patterns in adult hawksbill turtles after their nesting season, which peaks during October to February (Mortimer et al. 2020). These green and hawksbill turtle tracking data are being used to inform marine spatial planning broadly across the WIO, helping, for example, to determine boundaries of protected areas in the Seychelles. Investigation of foraging grounds within the MPA have led to discoveries of extensive, deep-water seagrass meadows across the south-east Great Chagos Bank (Esteban et al. 2018). Little is known about these newly discovered habitats, but they appear to support abundant and diverse fish communities (Esteban et al. 2018). As marine mega-herbivores can act as indicators of the presence of seagrass meadows (Hays et al. 2018), future tracking of green turtles in BIOT may increase knowledge of the distribution of these important habitats broadly across the entire WIO. In addition, immature hawksbill and green turtles foraging at Diego Garcia are also being satellite tracked to assess their patterns of space use. 
Sand temperature monitoring has shown that the nesting beaches at Diego Garcia are particularly climate resilient with regard to incubation temperatures (Esteban et al. 2016). The sex of sea turtle hatchlings is determined by the temperature in the nest in the middle third of incubation. Around the world there is concern that, with a warming climate, populations are becoming increasingly feminised, as females are produced at warmer temperatures. A lack of male hatchlings may ultimately lead to population extinction. At many sites globally, hatchling production is already heavily female skewed (Hays et al. 2014). However, at Diego Garcia, the sand at nest depths is relatively cool, most likely because of a combination of heavy rainfall and shading provided by vegetation behind the nesting beaches. As a consequence of these cool incubation temperatures, it is estimated that hatchling sex ratios are currently balanced (Esteban et al. 2016). Hence, in scenarios of climate warming, excessive feminisation of hatchlings will be much less likely to occur in the Chagos Archipelago than at most other nesting sites around the world. The Chagos Archipelago also supports immature foraging green and hawksbill turtles and ongoing work with drone surveys is estimating the size of these populations and their regional importance (Schofield et al. 2019).
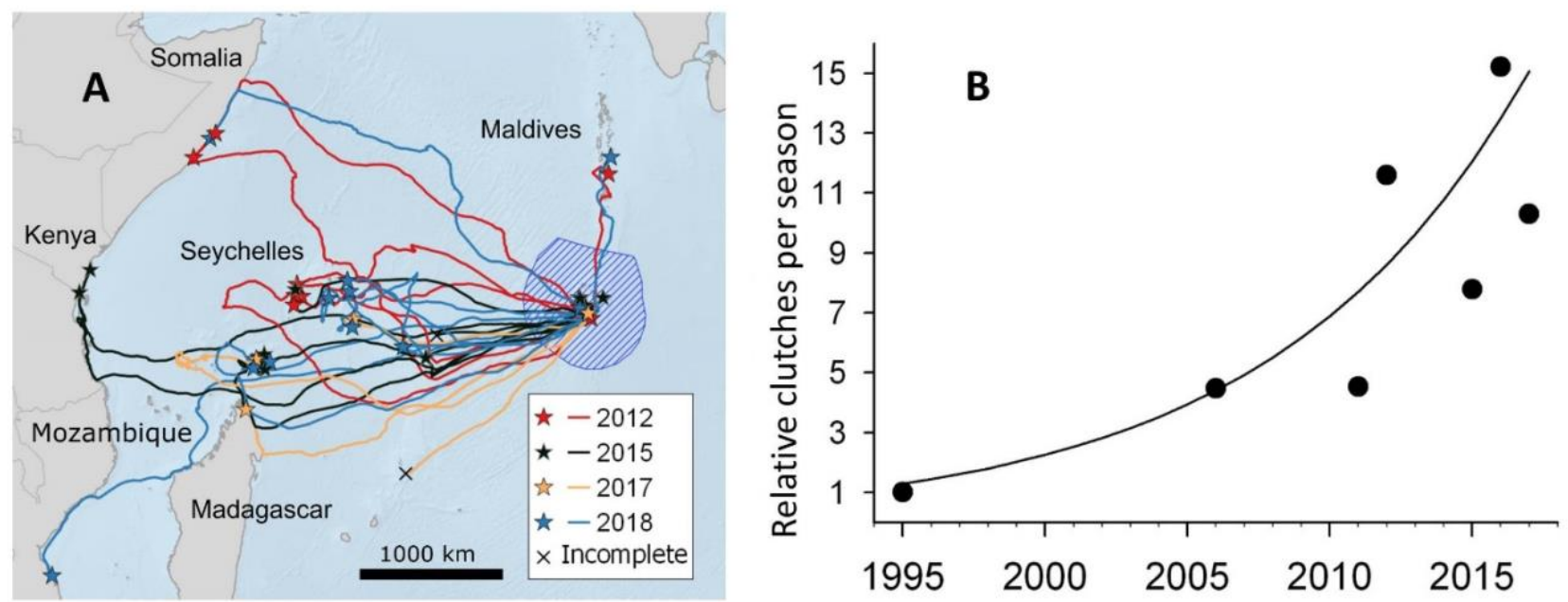

Fig. 4 The value of the Chagos Archipelago for sea turtles. a The archipelago provides a nesting sanctuary for green turtles that forage at distant sites throughout the Western Indian Ocean. Tracks of 35 adult female green turtles are shown, with individuals equipped with tags on nesting beaches on Diego Garcia and then dispersing widely at the end of the nesting season. The extent of the MPA is indicated by the blue hatched area. Stars denote the foraging locations of turtles, i.e. the end-point of migrations where turtles remained for many months before tags failed (modified from Hays et al. 2020). b The significant positive trend ( $p<0.01, r^{2}=0.88$ ) in the estimated number of green turtle clutches laid throughout the Chagos Archipelago. Numbers are scaled relative to those estimated in 1995, i.e. abundance in 1995 appears as one, to highlight the extent of the increase (modified from Mortimer et al. 2020). Between 2001-2018, the estimated mean number of clutches per year throughout the archipelago was 20,500 (Mortimer et al. 2020).

\section{The BIOT MPA protects globally significant seabird populations}

Research in the Chagos Archipelago has reinforced the important role seabirds play in tropical marine ecosystems. The WIO has been estimated to support $\sim 19$ million seabirds of 30 species, with the Chagos Archipelago supporting $~ 1$ million (or 5\% of the WIO total) individuals (Danckwerts et al. 2014). However, their status and distribution required updating, and until recently virtually 
nothing was known about their at-sea distribution. A recent synthesis of seabird status and breeding distribution across the Chagos Archipelago based on visits to all 55 islands, estimated 281,596 breeding pairs of 18 species (Fig. 5a). Of these, 96\% comprised three species, the sooty tern (Onychoprion fuscatus 70\%), lesser noddy (Anous tenuirostris 18\%) and red-footed booby (Sula sula $8 \%$ ) (Carr et al. 2020). Assuming 50\% breeding success, 281,596 breeding pairs (563,192 individuals) will produce 140,798 offspring, equating to $\sim 704,000$ breeding adults and immatures, or $\sim 4 \%$ of the regional total (Dankwerts et al. 2014). Current estimates are considerably lower than those proposed by Danckwerts et al. (2014), and there is strong evidence from early visiting naturalists (Bourne 1886) and guano mining records (Edis 2004, Wenban-Smith and Carter 2017) to suggest this is a fraction of the historic breeding seabird populations. Yet, it is unclear whether trends observed in BIOT are representative of the WIO. Therefore, updated estimates from across the WIO are now needed to reassess the status of breeding seabirds for this region.

At-sea behaviour and distribution of one of the most widely distributed and abundant species in the archipelago, the red-footed booby, is being revealed through the deployment of GPS loggers on breeding adults. Tracking reveals adults commute long-distances over relatively straight paths to feed in deeper waters beyond the Great Chagos Bank (Fig. 5b) and suggests at-sea segregation as seen elsewhere with seabirds from different colonies (Wakefield et al. 2013). As the vast majority of individuals remained within the MPA (Fig. 5b), the lack of commercial fishing within the MPA may help ensure high availability of forage fish and reduce threats from fisheries bycatch. The restriction of suitable breeding habitat due to the persistence of introduced rats and associated abandoned coconut plantations across $95 \%$ of the terrestrial landmass, remains a constraint to seabird recovery and the MPA delivering its full potential as a seabird sanctuary, although a feasibility study for eradicating rats across the archipelago has recently been completed.
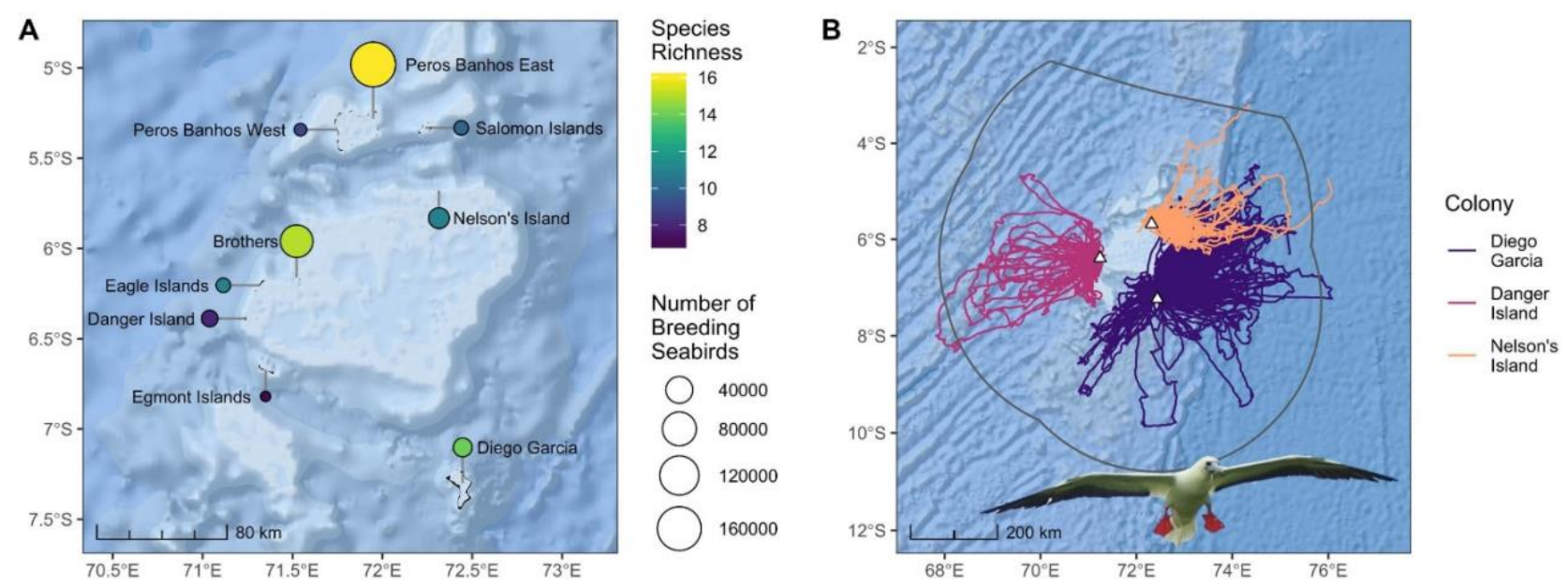

Fig. 5 Seabird abundance and movements. a Seabird species richness and abundance varies across the Chagos Archipelago. Data are from breeding seabird counts on all 55 islands 2008-2018 (Carr et al. 2020). b Centrally placed red-footed boobies breeding on the Chagos Archipelago largely forage within the MPA and show evidence of colony-specific at-sea segregation. Data are from 192 individuals at three colonies (DG: Diego Garcia, 2016-18, n=99; DI: Danger island, 2019 n=30; NI: Nelson's Island, 2018-19, n=63). Study colony locations are marked with triangles and the grey line delineates the MPA.

\section{The large no-take MPA encompasses important pelagic wildlife}

The relatively recent establishment of very VLMPAs, combined with the logistical and methodological challenges of sampling remote, expansive regions means that empirical data on the 
effectiveness of these MPAs for pelagic species are currently limited and conclusions are sometimes conflicting. Some studies suggest that MPAs are beneficial for mobile species, with the benefits of MPAs increasing with size, remoteness and age (Edgar et al. 2014). The BIOT MPA therefore represents an excellent reference site for such studies.

Since the establishment of the MPA, electronic tagging studies have reported, albeit with relatively low numbers and limited durations, higher than expected residency of pelagic fish species, such as silky sharks (Carcharhinus falciformis), sailfish (Istiophorus platypterus) and yellowfin tuna (Thunnus albacares) (Carlisle et al. 2019). The historical fishing record shows that large yellowfin tuna have also been reported to occur in the archipelago year-round (Curnick et al. 2020). Further, activity spaces of all pelagic species tagged around the Chagos Archipelago were significantly smaller than the extent of the MPA, suggesting it may be large enough to provide a refuge for extended periods of time (Carlisle et al. 2019).

Increased understanding of large pelagic species around the Chagos Archipelago has also been informed through the use of fisheries independent mid-water stereo-BRUVS (Fig. 2f). Assessments of pelagic richness and biomass using mid-water stereo-BRUVs (in 2012, 2015 and 2016) showed variation among pelagic habitats associated with atolls, seamounts and a deep-sea trench (Meeuwig unpubl. data). This is consistent with historical fisheries data that show high spatial heterogeneity in the distributions of species such as yellowfin tuna (Dunn and Curnick 2019). Pelagic richness and biomass around the Chagos Archipelago are also relatively high compared to global averages (Letessier et al. 2019).

The BIOT MPA was established for biodiversity conservation and not as a fisheries management tool. Studies elsewhere have shown benefits to adjacent tuna fisheries by VLMPA establishment (Boerder et al. 2017) and residency behaviour in yellowfin tuna to remote locations (Richardson et al. 2018). Yet a recent study of commercial catch data found no direct evidence that indices of yellowfin tuna abundance have improved in the areas immediately surrounding the MPA (Curnick et al. 2020). However, since the MPA's establishment, mismanagement of the yellowfin tuna fishery and a failure to adhere to catch reduction measures (Andriamahefazafy et al. 2020) has resulted in the stock being downgraded to "overfished and subject to overfishing" since 2015 (IOTCSC21, 2018). It is therefore not surprising that a single MPA one twelfth of the size of the fished region would be sufficient to turn around such declines, arguing the need for greater regional protection.

All pelagic shark species evaluated by the Indian Ocean Tuna Commission (IOTC) - with the exception of the blue shark (Prionace glauca) - have no or uncertain stock assessments (IOTCSC21 2018). Tracking studies have shown that pelagic sharks may travel across the Indian Ocean to the BIOT MPA, providing further evidence that the MPA may provide an important sanctuary for this group (Queiroz et al. 2019). So, while tracking data confirm sometimes protracted residence of pelagic species within the BIOT MPA (Carlisle et al. 2019) and BRUVs data show high pelagic species richness (Letessier et al. 2019), benefits may also be partly negated by overfishing in the surrounding region (IOTC-SC21, 2018, Curnick et al. 2020) and/or the ongoing IUU fishing activity (see below). Combined, these initial studies suggest that the BIOT MPA and its habitats could have considerable benefits for pelagic wildlife, particularly in the context of high fishing pressure in the region (Kroodsma et al. 2018).

\section{The BIOT MPA hosts exceptionally high cryptofauna diversity}

First estimates of the decapods in the Chagos Archipelago, one of the most speciose cryptofauna groups on coral reef microhabitats (Stella et al. 2011), recorded 1,868 individuals across 164 nominal species on 54 dead coral colony microhabitats (Head et al. 2018). This number of species is exceptionally high relative to similar studies in other locations (e.g. Preston and Doherty 1990; 
Plaisance et al. 2009; Enochs and Moanzello 2012; Head et al. 2018) and community structure is unusual due to a prevalence of obligate coral-dwelling decapods, such as Trapezia crabs (Head et al. 2015). Studies are now being undertaken across the archipelago to identify the most important environmental drivers of cryptofauna communities.

\section{The BIOT MPA protects diverse mesophotic coral ecosystems}

Mesophotic coral ecosystems (MCEs) are typically found at depths of 30m to $>150 \mathrm{~m}$ (Turner et al. 2017). Much of our knowledge of MCEs in BIOT is based on diver surveys from the 1970s (Sheppard 1980) and a small number of brief ROV surveys in 2016 (Andradi-Brown 2019). Building on these studies, in late 2019, high-resolution multibeam and a sophisticated ROV fitted with a HD camera were used to conduct extensive surveys of both upper and lower mesophotic communities from 30-150 m at seven sites around Egmont Atoll and Sandes Seamount. Preliminary analysis has revealed diverse and abundant MCEs at all locations surveyed, hosting communities of zooxanthellate scleractinian corals, soft corals, sea fans and sponges. A number of scleractinian coral specimens were also sampled at multiple sites and depths during the surveys. Using molecular techniques, work is ongoing to identify the species of corals sampled and to assess genetic connectivity among shallow and mesophotic reefs. Preliminary observations indicate that the MCEs of BIOT offer huge potential in the level of diversity they encompass and the extension of the shallow-water reefs into deeper waters, which is especially pertinent given recent bleaching events in the region (Head et al. 2019). Thus, the BIOT MPA has significant value in protecting extensive areas of diverse mesophotic coral ecosystems, which have the potential to support both local and regional shallow-water reefs in the face of climate change.

\section{Long-term protection preserves habitat connectivity, natural behaviours and ecological relationships}

Remote areas like the BIOT MPA can act as natural laboratories that deepen our ecological understanding of reef ecosystems. The BIOT MPA is home to numerous species of seabirds and mobile teleost and elasmobranch fishes that play an important role in connecting discrete habitats. Due to their proximity to deeper waters, the atoll ecosystems are spatially heterogeneous and temporally dynamic with resource availability continually shifting under the influence of diel and seasonal cycles, as well as oceanographic processes. Quantifying connectivity across these seascapes is important for understanding the degree to which populations should be treated and managed as distinct units (Jacoby and Freeman 2016) and to uncover the functional role that mobile species play in nutrient transfer (Williams et al. 2018a), predation pressure (Heupel et al. 2014) or local measures of biodiversity (Benkwitt et al. 2020).

Seabirds in the Chagos Archipelago forage in the open ocean, far from the islands on which they roost and breed (Fig. 5). In doing so, they transfer large quantities of nutrients from pelagic food webs to terrestrial systems. This pathway of nutrient flow from seabird guano to coral reefs is illustrated by elevated nitrogen signatures in terrestrial soils and plants, benthic marine organisms, such as sponges and algae, and marine consumers, including herbivorous damselfish (Graham et al. 2018). These nutrient subsidies, in turn, bolster the growth rates of individual coral-reef fishes, and lead to enhanced biomass and ecosystem functioning (including secondary productivity, grazing and bioerosion rates) of entire fish assemblages (Graham et al. 2018; Benkwitt et al. 2020). Contrary to anthropogenically-derived nutrient inputs, which negatively affect coral physiology and increase susceptibility to bleaching (Wooldridge and Done 2009; Wiedenmann et al. 2013; D'Angelo and Wiedenmann 2014; MacNeil et al. 2019; Donovan et al. 2020), naturally-derived nutrients provide nitrogen and phosphorous in optimal ratios and can thus increase coral growth (Shantz and Burkepile 
2014; Savage 2019) and may reduce susceptibility to heat stress (Ezzat et al. 2016). Indeed, nutrient inputs from seabirds can also alter the response of coral reefs to marine heatwaves, as demonstrated in part by the proliferation of calcifying algae (e.g., crustose coralline algae) around islands with abundant seabirds following the 2015/2016 mass coral bleaching event in the Chagos Archipelago (Benkwitt et al. 2019) (Fig. 6).

Since 2013, a large network of acoustic receivers installed across the archipelago, and annual deployments of both acoustic and satellite tags, are beginning to reveal the extent to which large mobile fishes utilise and link different areas across atoll archipelagos (Carlisle et al. 2019; Jacoby et al. 2020). Acoustic tracking of grey reef and silvertip sharks, both of which are a principal target of IUU fishing activity in the BIOT MPA, has revealed a few key locations where connectivity is unexpectedly high (Jacoby et al. 2020). A closer look at the reef shark assemblage, using network analyses of the telemetry data, reveals how these species play different roles in connectivity across the MPA, with grey reef sharks exhibiting more residential/site-attached behaviour, while silvertip sharks have considerably more dynamic movements (Carlisle et al. 2019; Jacoby et al. 2020). Interestingly, the movement patterns, and thus connectivity of these sympatric species, vary both diurnally and seasonally suggesting both spatial and temporal segregation within the reef shark assemblage, corroborating patterns observed through stable isotope analyses in BIOT (Curnick et al. 2019).

For large-bodied, wide-ranging planktivores like reef manta rays (Mobula alfredi), habitat selection is strongly influenced by prey availability (Stewart et al. 2018). Telemetry and biologging approaches are beginning to show that the reef manta rays found in the BIOT MPA frequently utilise atoll ecosystems, sometimes with long-term site fidelity and aggregation sites, such as at Egmont and Salomon atolls (Carlisle et al. 2019; Harris 2019; Andrzejaczek et al. 2020). Connectivity is greatly facilitated by dynamic reef manta movements over frequent short-distances $(<10 \mathrm{~km})$ and infrequent long-distance $(>200 \mathrm{~km})$ horizontal movements as well as dives recorded as deep as $500 \mathrm{~m}$ (Andrzejaczek et al. 2020). Characterising the portion of the population that is highly mobile will enable us to better understand drivers of connectivity across the archipelago.

A range of unusual or rarely observed behaviours have been studied in the Chagos Archipelago, which are likely linked to its isolation. Examples include moray eels (Gymnothorax pictus) diurnally hunting shore crabs on land (Graham et al. 2009), day octopus (Octopus cyanea) hunting cooperatively with fishes (Bayley and Rose 2020) and coconut crabs (Birgus latro) predating on adult seabirds (Laidre 2017). All such behaviours are rarely seen, if at all, in highly humanimpacted systems elsewhere (Graham and McClanahan 2013). Furthermore, parrotfish and surgeonfish in the archipelago exhibit reduced 'flight' behaviour compared to fished areas, showing either an inherited or learned effect of wariness in response to fishing pressure (Januchowski-Hartley et al. 2015). Protected or wilderness areas can therefore provide a valuable window into the natural ecological interactions and behaviours, which have otherwise disappeared or been modified.

In remote systems such as the Chagos Archipelago, characterised by high consumer biomass (Graham and McClanahan 2013), general ecological theories can be tested about relationships and behaviours. Such locations are ideal for investigating what mechanisms maintain trophic structure, drive variation in structure and complexity, and what the implications are for individual behaviours, species interactions, or food web stability and productivity (McCauley et al. 2012, 2018; Woodson et al. 2018). Current work in the Chagos Archipelago has just begun to test such broader ecological theories, for example, the biodiversity-ecosystem function relationship (Benkwitt et al. 2020). Thus, not only can remote MPAs like the Chagos Archipelago inform conservation, but also contribute to broader basic ecology research. 

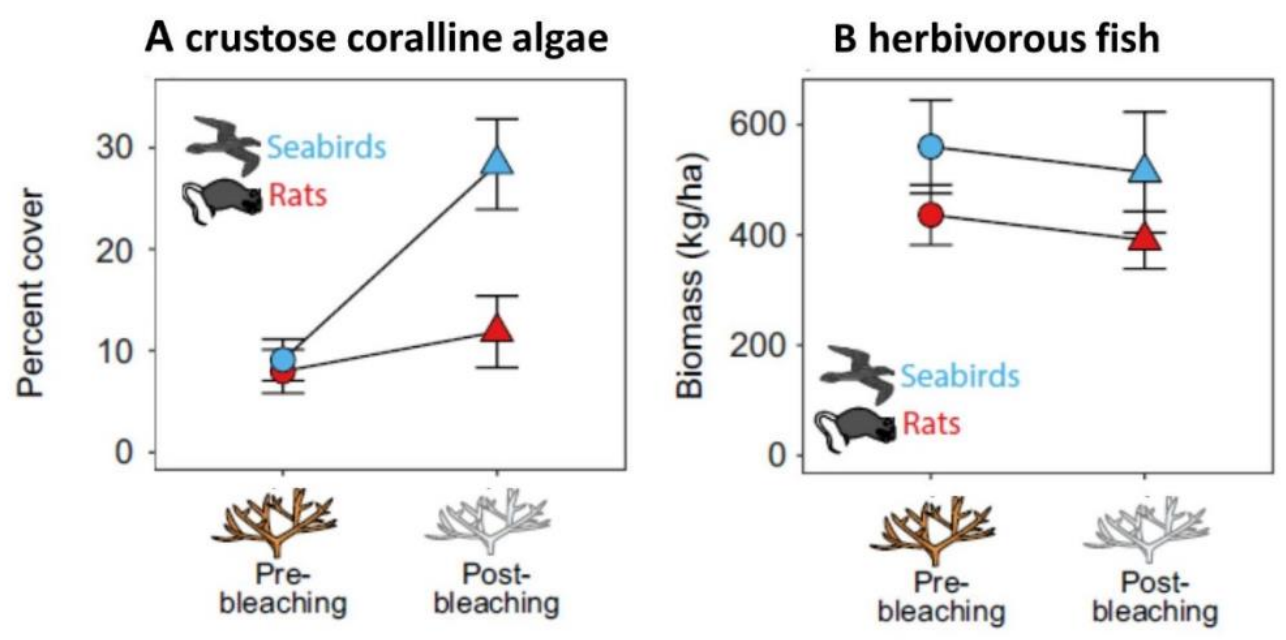

622

623

624

625

626

627

628

629

630

631

632

633

634

635

636

637

638

639

640

641

642

643

644

645

646

647

648

649

650

651

652

653
Fig. 6 Benefits of rat-free islands to coral reefs. On rat-free islands in the Chagos Archipelago, seabird guano supplies nutrients to the adjacent coral reefs. These nutrient subsidies, in turn, bolster the growth rates of individual coral-reef fishes, leading to enhanced biomass and ecosystem functioning. Additionally, these nutrient inputs from seabirds can also alter the response of coral reefs to marine heatwaves, as demonstrated by responses to the 2015/2016 mass coral bleaching event. Even though seabird nutrients did not enhance community-wide resistance to bleaching, they may still promote recovery of these reefs through their positive influence on a calcifying algae (e.g., crustose coralline algae) and $\mathbf{b}$ herbivorous fishes (modified after Benkwitt et al. 2019).

\section{Understanding the physical oceanography driving biodiversity across the archipelago}

Deep oceanic flushing of cold water into the atolls across the Chagos archipelago drives plankton distributions and ecosystem functioning within the sheltered lagoons (Sheehan et al. 2019). Seamounts are also particularly important features within BIOT and include relatively shallow features such as the Sandes and Swartz seamounts west of Diego Garcia. Their biological significance has been suggested from acoustic surveys during which backscatter indicated 100x higher biomass in close proximity to seamounts and a "halo" influence of the seamount of approximately $1.8 \mathrm{~km}$ (Letessier et al. 2016). Recognised as a hotspot for pelagic sharks (Tickler et al. 2017), studied seamounts exhibit internal lee waves that flush the summits with nutrient rich, cool water (Hosegood et al. 2019). The steep and narrow seamounts found throughout the archipelago, however, prohibit the formation of Taylor Columns that are frequently cited as the mechanism causing the local retention of nutrients and the subsequent primary production over seamounts (Genin, 2004). Instead, the local generation of turbulent and energetic currents associated with the lee waves are proposed to encourage schooling behaviour of lower trophic levels upon which sharks prey and thereby explain the corresponding acoustic signature in biomass over the drop-off where the internal wave impacts are most pronounced. Acoustic surveys during 2019 over the slopes surrounding Egmont Island, further confirmed that the intensification of biomass is not limited to seamounts but extends to the steep slopes surrounding islands and atolls throughout the archipelago (Fig. 7). 

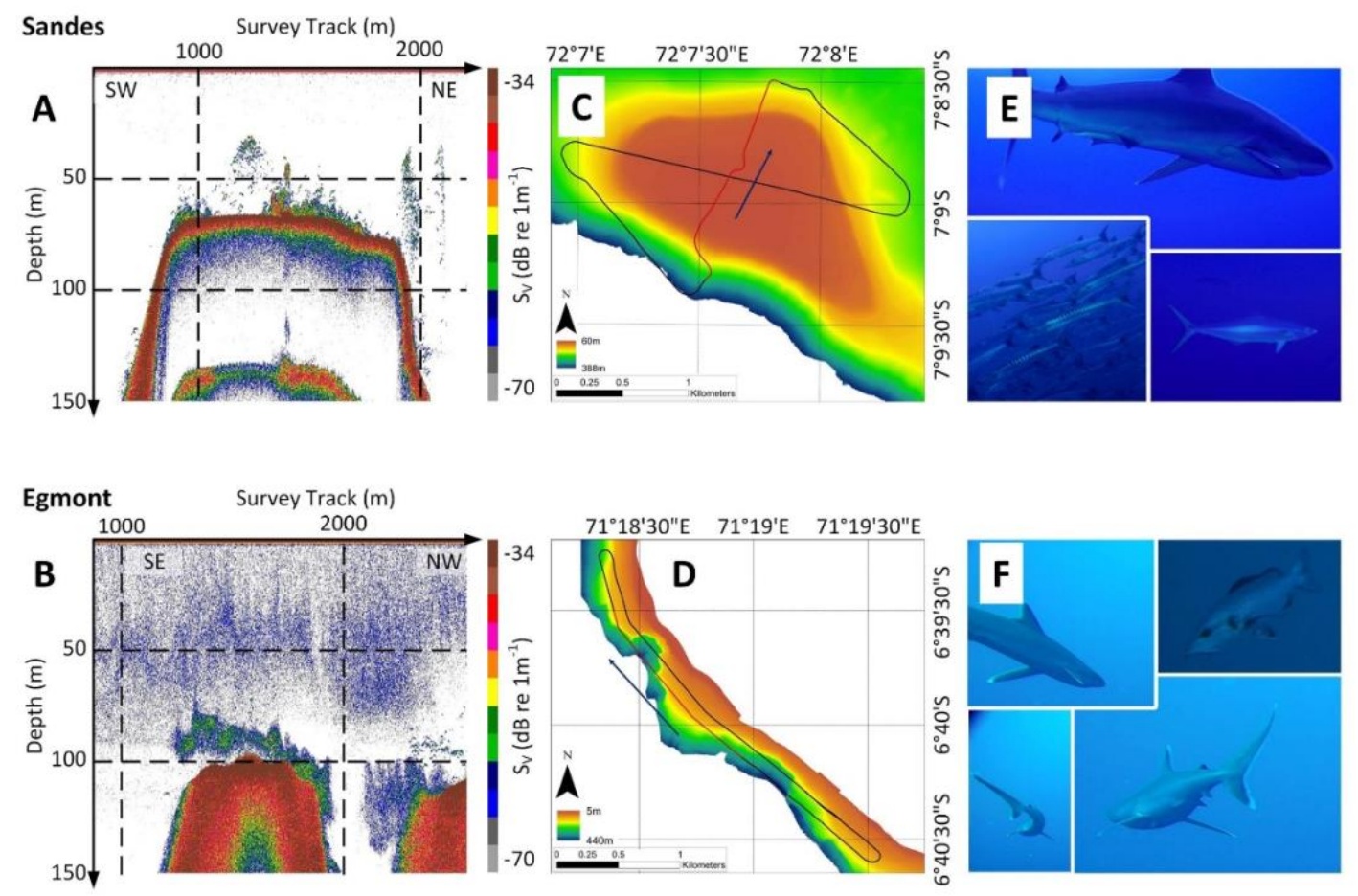

Fig. 7 Use of sonar and cameras to reveal mid-water fauna. $38 \mathrm{kHz}$ raw Sv echograms of submerged banks at a Sandes and b Egmont (lower). Dense dark red echogram returns show the seabed and second echo at Sandes, with aggregations of biomass (fish and zooplankton) in shallower water, confirmed opportunistically using camera drops. c and $\mathbf{d}$ cruise tracks showing seabed depth (with red showing echogram portion. e and $\mathbf{f}$ camera validation of targets (Hosegood, Williamson \& Embling, unpublished data, 2019).

\section{Key ongoing threats}

\section{Illegal fishing poses a major threat to vulnerable habitats and species in the BIOT MPA}

IUU fishing activity is a considerable challenge inside the BIOT MPA. Historically, IUU occurred alongside a licensed tuna fishery and it has persisted since the fishery closure in 2010 (Fig. 8). From 2002 to 2018, the majority (78\%) of vessels have originated from Sri Lanka, although vessels from south-west India are also active (12\% of sightings). The Sri Lankan vessels are medium-sized (10-15 $\mathrm{m}$ ) operating both gill-net and long-line gears, often using illegal wire trace to target sharks (MRAG, 2015) (Fig. 8).

Enforcement occurs primarily through use of the BIOT Patrol Vessel, which is responsible for the detection and apprehension of IUU fishing vessels within the MPA. Ferretti et al. (2018) estimated that 20 to 120 boats enter the area annually. However, determining the actual level of IUU threat is complicated by temporal and spatial variation in patrolling effort. Although patrolling has occurred since 1996, patrol effort data have only been logged consistently since December 2013. That notwithstanding, trends in IUU vessel encounters suggest that the MPA's implementation has had little discernible impact on the IUU activity (Fig. 8). Spatial and temporal analyses of all vessel encounters suggest that suspected IUU is focused on the shallow reefs and northern sectors (Fig. 8) with peaks in activity in the months of May-June and December (MRAG, unpublished data).

IUU fishing appears to have driven declines in some shark populations within the MPA (Ferretti et al. 2018; Tickler et al. 2019) and so may impair the MPA's function as a refuge for these species (Letessier et al. 2019). From the catch data, Ferretti et al. (2018) estimated that between 
6851,745 and 23,195 sharks were caught between 1996 and 2015 within the MPA. The number of sharks 686 seen per scientific dive in the archipelago reduced from $\sim 4$ in the 1970s to $\sim 1$ since the mid-1990s 687 (Graham et al. 2010). Recent re-surveys (2018-2019) of the reef fish community structure and 688 biomass on the outer reef slopes at the same sites, using the same methods, and by the same 689 observer, have indicated substantial declines in biomass (Graham et al. unpubl. data) that have also 690 sharks were observed in BRUVS surveys within the atoll lagoons between 2012 and 2016 (Meeuwig unpubl. data). Important exploited families, such as serranids and lethrinids, decreased by $74 \%$ and 53\%, while coral feeding groups, such as chaetodontids, declined by $37 \%$ (Meeuwig unpubl. data). Among the shark species, whitetip reef sharks (Triaenodon obesus) declined by $81 \%$ and $60 \%$ in relative abundance and size, respectively. The grey reef shark declined by $76 \%$ in relative abundance and by $4 \%$ in size. The tawny nurse shark (Nebrius ferrugineus) reduced in relative abundance and size by $37 \%$ and $60 \%$ (Meeuwig unpubl. data). These declines in relative abundance and size were coincident with recorded poaching incidents (MRAG 2015).

Currently, the BIOT Patrol Vessel has to balance patrol activities, border protection, scientific research support, as well as refuelling and crew changes outside the territory. As such, there have been recent efforts to improve enforcement capacity through the trialling of additional technologies within the MPA through the UK's Blue Belt Programme with a Technology Roadmap under development. Importantly, the continued threat from IUU fishing highlights the need to improve monitoring and understanding of the human dimensions (e.g. socio-economic drivers of illegal fishing) of large MPAs which, although remote, are interconnected within wider socioecological systems (Gruby et al. 2015). Concerns have also been raised about the adequacy and effectiveness of punitive measures, whereby risks of capture combined with low costs associated with any arrest may still leave IUU fishing as a viable option for some fishers. 

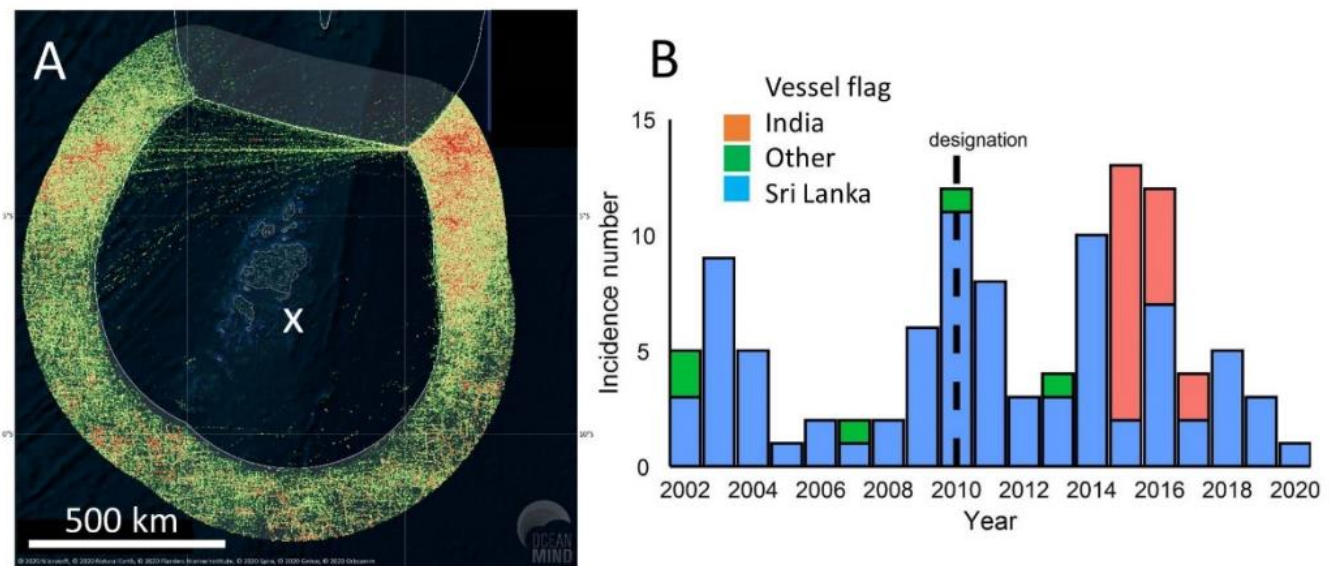

712

713

714

715

716

717

718

719

720

721

722

723

724

725

726

727

728

729

730

731

732

733

734

735

736

737

738
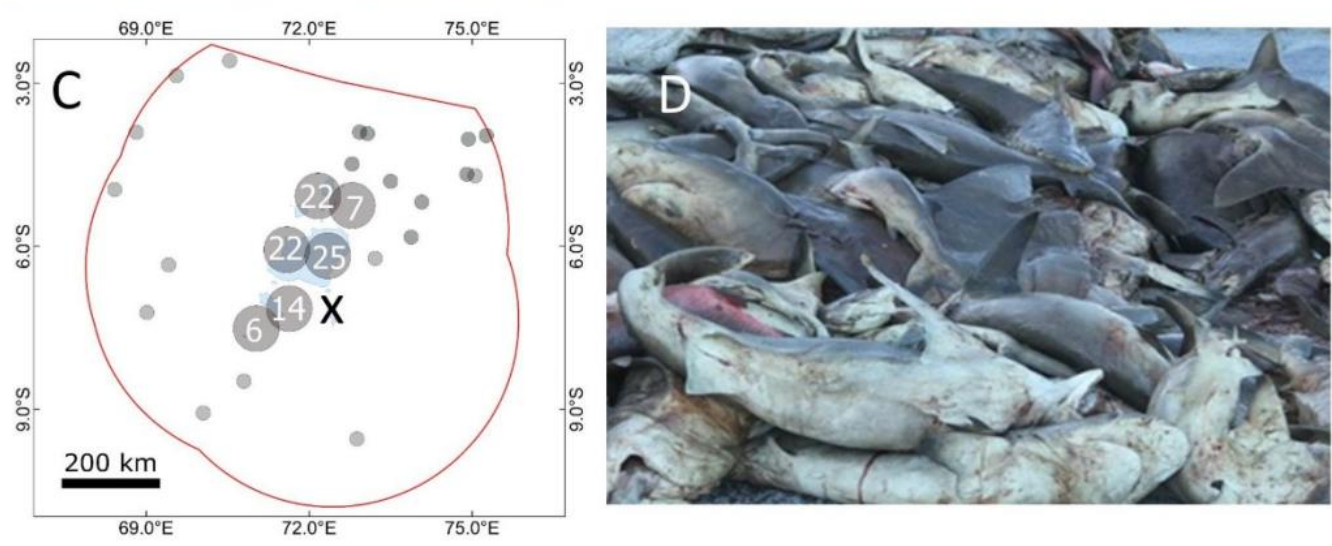

Fig. 8 The threat of Illegal, Unreported and Unregulated fishing. a Heat-map of AIS activity from fishing fleets operating in the British Indian Ocean Territory area of interest (BIOT AOI) between 1 January 2014 and 31 December 2019. Fishing vessel identities were confirmed and the activity shown is restricted to AIS transmissions associated with speeds between 0.5-5 knots, speeds typically associated with fishing operations and fishing activity at sea. The extension and level of fishing activity is represented by positional densities that vary from: black = no activity, transparentgreen $=$ lower activity (low positional densities) to red/higher activity (hotspots). Legal activity within 3 nautical miles of Diego Garcia (white cross) and slow transits to and from port are not shown. The activity in the northern MPA is produced by small scale commercial fishing vessels (fleet) transiting regularly at slow speed and shaping these lanes between the northeast and northwest boundaries. However, these vessels very frequently deploy fishing gears inside the MPA while on transit and need to be accounted for within the overall fishing activity. Overall, fishing activity is high and widespread through the adjacent high seas. The east and west boundaries of the MPA show high risk due to fishing activity encroaching and entering the marine protected area, with short and repetitive incursions. Additionally, low positional densities inside the southwest MPA are produced from infrequent longer incursions. b Vessels suspected of IUU activity that were either detained by authorities or escaped capture from 2002-2020. The dashed line indicates MPA implementation (2010). Flag of origin indicated in legend, other = Indonesia, Mauritius, Japan, Taiwan. Source: MRAG, unpublished data, 2020. c Location of detained or escaped vessels suspected of IUU from 2002-2020. Numbers represent the number of vessels from that same site. The cross indicates the location of Diego Garcia. Source: MRAG, unpublished data, 2020. d An example of a confiscated catch in the BIOT MPA (photo Tom B Letessier). 


\section{Coral reefs in the Chagos Archipelago are not immune to bleaching events}

Reefs in the Chagos Archipelago have repeatedly been impacted by global coral bleaching events, and the current ecological condition of the reefs suggests they are presently at a critical recovery stage. While coral cover is starting to increase, structural complexity changes are likely to continue for several years, as the remaining reef continues to degrade due to intense external and internal biophysical erosion. Shallow reefs are increasingly covered by the bioeroding sponge Cliona spp., decreasing the area suitable for new coral settlement. Additionally, an outbreak of coralline fungal disease has been observed in 2018, potentially impacting coral recruitment further (Williams et al. 2018b). Indeed, data from 2017 indicates that the density of newly settled coral recruits ( $<1$ year-old) has reduced by approximately $90 \%$ since 2013 (Fig. 3b). Larger young corals ( $>1$ year) are present in greater numbers, though most are located on unstable dead table corals or mobile rubble (Fig. 3f), and therefore are likely to experience high mortality rates (Sheppard et al. 2017). Measured growth rates for several coral species were also comparatively low in 2018-2019, suggesting prolonged effects of heat stress on coral physiology (Lange \& Perry 2020). Since the late 1970s, several coral species and key species assemblages in the Chagos Archipelago have gone regionally or functionally extinct. Although species diversity remains high at present, local extinctions may increase in the future, following a spiral of positive feedback through low recruitment and lack of suitable settlement substrate (Sheppard et al. 2020).

Importantly, the remote and protected nature of the BIOT MPA has previously supported rapid coral community recovery following widespread mortality in 1997-1998, giving hope for future recovery (Sheppard et al. 2008). However, it is unclear whether all reefs will restructure in the same way that they did after 1998, whether recovery will be as fast at all sites, or whether some sites may regime-shift to other states. The return of Acropora spp. dominated communities will be crucial to restore the key geo-ecological functions of habitat complexity and carbonate production that local reefs delivered pre-bleaching (Lange \& Perry 2019). Ultimately, the primary control on coral reef recovery in the Chagos Archipelago will be the recurrence intervals and magnitudes of future heat stress events. Unfortunately, BIOT is predicted to see a large increase in the frequency of annual severe bleaching events in the coming decades, even under conservative emission scenarios (van Hooidonk et al. 2016). Additionally, atmospheric nitrogen deposition is projected to increase in the future, negatively affecting even remote coral reefs (Chen et al. 2019).

\section{Discussion}

\section{Future research directions for large MPA science}

Here, we have shown how recent research in the BIOT MPA has helped to identify not only its conservation benefits, such as increased abundance of various species, habitat diversity and resilience, but also the physical and ecological processes that drive these benefits. Fundamental to these findings has been the multi-year monitoring that has identified important conservation successes, such as the increase in nesting turtle numbers, the recovery of coral reefs following bleaching and mortality, or the preservation of natural processes such as seabird subsidies improving reef vigour. Global climate change remains a huge threat to coral reefs, both within the BIOT MPA and elsewhere (e.g. Bates et al. 2019), with the frequency of temperature anomalies and extent of ocean acidification likely to play key roles in dictating the type of shallow reefs that survive into the future. Such monitoring needs to be continued and expanded. Long-term monitoring of mesophotic reefs will help identify if they are more resilient than shallow reefs to global heat waves and if these deep reefs help the recovery of bleached areas. It will also identify if the encouraging trends of increased sea turtle nesting continue in the future as well as the impact of potential threats to sea turtle and seabird nesting posed by rising sea levels. Finally, long-term monitoring of pelagic species 
at BIOT will also demonstrate the degree to which the MPA generates conservation benefits for mobile exploited species that contribute to regional fisheries.

The BIOT MPA houses regionally significant fish assemblages that play an important role in the resilience of its coral reefs to climate threats but that continue to be impacted by IUU fishing. Future research should focus on improving the understanding of the scale and nature of IUU fishing in the MPA, as well as its drivers to assist with improved enforcement and compliance. Targeted research is also needed to develop efficient mechanisms to combat IUU fishing given the huge area of the BIOT MPA poses significant logistical challenges. Innovative methods to combat IUU fishing have started to be implemented, often with methods tailored to target the specific IUU fishery (e.g. Tickler et al. 2020) and need expanding.

It is important to assess the extent of animal movements in relation to MPAs so that threats to mobile species can be identified and benefits of different sized protected areas can be objectively assessed (Dwyer et al. 2020). Given that many marine species may travel many thousands of km (Hays and Scott 2013), even the largest protected areas, such as the BIOT MPA, may sometimes not encompass the full extent of marine animal movements. While a number of species have been tracked (e.g. green turtles and red-footed boobies) important knowledge gaps remain. For seabirds, their movements outside the breeding season remain unknown. Initial studies suggest that the BIOT MPA and its habitats could have considerable benefits for pelagic fish. Yet, a challenge remains to humanely capture and equip a large enough number of individuals to assess the overall patterns of movement for pelagic fish species. Interestingly, some pelagic sharks equipped with tags 1000s of $\mathrm{km}$ away off southern Africa, have travelled across the Indian Ocean to the BIOT MPA (Queiroz et al. 2019). So, for some taxa, tagging studies conducted within the BIOT MPA might usefully be blended with studies being conducted elsewhere to assess patterns of space use across the Indian Ocean and more broadly. The huge value of such data-sharing in animal tracking studies has recently been emphasised (Sequeira et al. 2019). In some areas, such as marine animal tracking, routes by which data can drive conservation outcomes have been identified (Hays et al. 2019) and the tracks of turtles equipped in the Chagos Archipelago that migrate broadly are already being used to help direct marine spatial planning both in BIOT and the Seychelles.

Little is known about some important habitats in the BIOT MPA. While coral reefs have been a focal habitat for concerted research for some time, a depth limit of $25 \mathrm{~m}$ is placed on diving activities to minimise the risks in such a remote location. Yet most of the Great Chagos Bank, the world largest atoll structure, is between 25 to $100 \mathrm{~m}$ deep. Deeper areas are only starting to be explored with, for example, the use of drop-down cameras and ROVs (remotely operated vehicles). Furthermore, research in the BIOT MPA to date has also been focussed on returning to sites previously surveyed, in order to build a robust, long-term time-series. Yet this has resulted in the majority of the archipelago remaining unexplored and under-studied, such as the seagrass beds on the Great Chagos Bank. Here, there may be a very useful synergy between animal tracking studies and habitat surveys, with hot-spots of space use identified in tracking studies, being used to direct insitu habitat surveys, i.e. tracking animals helps identify areas of particular interest (Jacoby et al. 2020). An example here is the use of green turtles to identify the location of seagrass beds on the Great Chagos Bank that were hitherto unknown (Esteban et al. 2018).

\section{Lessons learned of relevance to other VLMPAs}

While the number of MPAs across the world is increasing, their benefits continue to be debated (Edgar et al. 2014, Bruno et al. 2019). Set against this backdrop, case studies showing the value of MPAs are important (Murray and Hee 2019). One feature that is evident from much of the recent research is the importance of long-term monitoring throughout the system. It is well established how the value of ecological time-series grows as the time-series lengthen (e.g. see Edwards et al. 2010), allowing the drivers of long-term changes and inter-annual variability to be more clearly identified. It is therefore important for long-term monitoring to occur in VLMPAs and that it embraces new 
839 technology. Such monitoring allows assessment of the success of conservation actions and whilst highly protected zones have benefited fishes relative to partially protected zones, this high level of protection has had no impact on the rate of coral decline (Toth et al. 2014) which is driven both by large scale factors such as poor water quality and climate-related storms and bleaching.

That the BIOT MPA, despite its extreme remoteness, remains subject to incursions of IUU fishing with a demonstrable impact on biodiversity demonstrates the need for more efficient mechanisms to combat IUU fishing. This may be a common issue with remote MPAs and necessitates the need for innovative methods to combat IUU fishing (Park et al. 2020). For example, in the territorial waters around French Islands in the Southern Ocean, radar detecting tags carried by albatrosses are being used to detect large ships operating illegally (Weimerskirch et al. 2020). Further, interactions between large static MPAs and mobile fishing gears, such as fish aggregation devices (FADS) (Bucaram et al. 2018) and industrial fishing fleets around their perimeters (Kroodsma et al. 2018; Curnick et al. 2020) need to be better understood. Given the huge fishing pressures in unregulated high seas fisheries outside protected areas, the importance of large MPAs for pelagic species protection has been stressed (Queiroz et al. 2019). Yet, we emphasise that large protected areas, such as the BIOT MPA, should not be considered as a silver bullet, but rather in conjunction with wider sustainable and effective fishery management regulations to provide the urgent conservation and management benefits needed for pelagic predators. The recent developments to expand the UN Convention on the Law of the Sea (UNCLOS) to include a new legally binding instrument on the conservation and sustainable use of marine life in Areas Beyond National Jurisdiction (General Assembly resolution 72/249) are therefore encouraging.

In addition to studying a range of marine habitats within MPAs, another important research direction is to better quantify the connections between terrestrial and marine environments. Although this research will take different forms in the BIOT MPA and other remote VLMPAs compared to smaller MPAs located closer to human population centres, prioritizing research and encouraging management across land-sea boundaries applies to all MPAs. Specifically, land-based nutrient pollution plays a large role in declining coral health, especially when coupled with increasing warming events (Wooldridge and Done 2009; Donovan et al. 2020). As a result, there have been recent calls to better regulate run-off from land adjacent to MPAs to mitigate continuing coral loss and enhance recovery following bleaching events (Lapointe et al. 2019; MacNeil et al. 2019). In contrast to these human-derived nutrients, natural nutrient subsidies, such as those provided by seabirds nesting on islands, may benefit coral reefs and enhance their resilience to global heat waves (Graham et al. 2018; Benkwitt et al. 2019). Thus, while one research and management priority within BIOT is the restoration of such natural nutrients (e.g., by eradicating invasive rats and restoring seabird populations), less remote MPAs will likely need to simultaneously reduce humanderived nutrient run-off to have similar benefits for coral reefs. Still, jointly managing terrestrial systems in conjunction with MPAs may be broadly applicable, and may increase the effectiveness of MPAs at conserving coral reefs and other nearshore habitats.

Cutting across all the marine science work in the BIOT MPA, an important goal is to maximise the translation of the accumulated data into positive conservation outcomes, a theme that pervades across MPAs more broadly (Lubchenco and Grorud-Colvert 2015). The BIOT MPA was one of the early wave of no-take VLMPAs implemented from 2006-2010 (with Papahānaumokuākea Marine National Monument, USA and Phoenix Islands Protected Area, Kiribati) as countries worked to meet Aichi Target 11 of $10 \%$ ocean protection by 2020 under the United Nations' (UN) Convention on Biological Diversity (CBD), later endorsed under Sustainable Development Goal 14. Today, only $5.3 \%$ of the world's ocean is protected with $2.5 \%$ highly protected in no-take MPAs (http://mpatlas.org/, accessed 26 May 2020). However, the UK government is leading the 30-by-30 initiative, pushing for at least $30 \%$ of the global ocean to be protected by 2030 with the hope that this goal will be ratified at the 2020 CBD Conference of the Parties, now rescheduled for 2021. Research 
from the BIOT MPA therefore provides important insights to inform policy commitments around ocean protection, including the need for greater regional protection, as part of the actions identified to rebuild ocean life (Duarte et al. 2020). Mechanisms to effectively achieve this science to policy interface will be aided by the UN Decade of Ocean Science for Sustainable Development (20212030). The wealth of new information from ongoing work in the BIOT MPA promises to help drive marine conservation both within the MPA and more broadly, which is, perhaps the most important legacy this work can leave.

\section{Author contributions}

This manuscript was conceived by GCH and ideas discussed and modified at a workshop led by HK and DC and held in London during September 2019. GCH, DC, IDL, CTP, DMPJ, HK, JJM, NG, NE, NLF and CEIH led the writing with all authors contributing. GCH and DC assembled the text and led the initial editing and all authors contributed to the final manuscript editing.

\section{Funding}

Major support came from the Bertarelli Foundation as part of the Bertarelli Programme in Marine Science. The Darwin Foundation supported BRUVS work by JJM and TBL. TeachGreen supported seabed BRUVS work (JJM). The Garfield Weston Foundation supported work on the oceanography and mesophotic reefs by NLF, CD, KLH, PH, CBE, BJW, EVS, MJA. Early coral reef and atoll work was supported by the Overseas Territories Environment Programme (CS, JT, MS), and Darwin Initiative Project 19-027 (JT, HK, CS) and Selfridges \& Co. (HK). Additional funding for tags was provided by the JSF Pollitzer Charitable Trust, The Rufford Foundation and the Ernest Kleinwort Charitable Trust through the Chagos Conservation Trust (DC).

Conflict of interest The authors declare that they have no conflict of interest.

\section{References}

Andriamahefazafy M, Bailey M, Sinan H, Kull CA (2020) The paradox of sustainable tuna fisheries in the Western Indian Ocean: between visions of blue economy and realities of accumulation. Sustainability Science 15:75-89. https://doi.org/10.1007/s11625-019-00751-3

Andradi-Brown DA, Dinesen Z, Head CEI, Tickler DM, Rowlands G, Rogers AD (2019) The Chagos Archipelago. In: Loya Y, Puglise K, Bridge T (eds) Mesophotic Coral Ecosystems. Coral Reefs of the World, vol 12. Springer. https://doi.org/10.1007/978-3-319-92735-0_12 Andrzejaczek S, Chapple TK, Curnick DJ, Carlisle AB, Castleton M, Jacoby DMP, Peel LR, Schallert RJ, Tickler DM, Block BA (2020) Individual variation in residency and regional movements of reef manta rays Mobula alfredi in a large marine protected area. Mar Ecol Prog Ser 639:137-53. https://doi.org/10.3354/meps13270

Appleby T (2015) The Chagos marine protected arbitration - a battle of four losers? Environmental Law 27:529-540. https://doi.org/10.1093/jel/eqv027

Ballantine B (2014) Fifty years on: Lessons from marine reserves in New Zealand and principles for a worldwide network. Biol Cons 176:297-307. https://doi.org/10.1016/j.biocon.2014.01.014

Ban NC, Gurney GG, Marshall NA, Whitney CK, Mills M, Gelcich S, Bennett NJ, Meehan MC, Butler C, Ban S, Tran TC, Cox ME, Breslow SJ (2019) Well-being outcomes of marine protected areas. Nature Sustainability 2:524-532. 
Barley SC, Meekan MG, Meeuwig JJ (2017) Species diversity, abundance, biomass, size and trophic structure of fish on coral reefs in relation to shark abundance. Mar Ecol Prog Ser 565:163-79. https://doi.org/10.3354/meps11981

Barley SC, Clark TD, Meeuwig JJ (2020) Ecological redundancy between coral reef sharks and predatory teleosts. Rev Fish Biol Fisheries 30: 153-172. https://doi.org/10.1007/s11160-019$\underline{09588-6}$

Bates AE, Cooke RSC, Duncan MI, Edgar GJ, Bruno JF, Benedetti-Cecchi L, Cote IM, Lefcheck JS, Costello MJ, Barrett N and Bird TJ (2019) Climate resilience in marine protected areas and the 'Protection Paradox'. Biol Cons 236:305-314. https://doi.org/10.1016/j.biocon.2019.05.005

Bayley DTI, Rose A (2020) Multi-species co-operative hunting behaviour in a remote Indian Ocean reef system. Mar Freshw Behav Physiol 53:35-42. https://doi.org/10.1080/10236244.2020.1746658

Benkwitt CE, Wilson SK, Graham NAJ (2019) Seabird nutrient subsidies alter patterns of algal abundance and fish biomass on coral reefs following a bleaching event. Glob Change Biol 25:2619-2632. https://doi.org/10.1111/gcb.14643

Benkwitt CE, Wilson SK, Graham NAJ (2020) Biodiversity increases ecosystem functions despite multiple stressors on coral reefs. Nat Ecol Evol. https://doi.org/10.1038/s41559-020-1203-9

Boerder K, Bryndum-Buchholz A, Worm B (2017) Interactions of tuna fisheries with the Galápagos marine reserve. Mar Ecol Prog Ser 585:1-15. https://doi.org/10.3354/meps12399

Bourne GC (1886) General observations on the fauna of Diego Garcia. Proc Zool Lond 1886:331334.

Bruno JF, Côté IM, Toth LT (2019) Climate change, coral loss, and the curious case of the parrotfish paradigm: Why don't marine protected areas improve reef resilience? Ann Rev Mar Sci 11:307-334. https://doi.org/10.1146/annurev-marine-010318-095300

Bucaram SJ, Hearn A, Trujillo AM, Rentería W, Bustamante RH, Morán G, Reck G, García JL (2018) Assessing fishing effects inside and outside an MPA: The impact of the Galapagos Marine Reserve on the Industrial pelagic tuna fisheries during the first decade of operation. Mar Pol 87:212-225.

Burkepile DE, Shantz AA, Adam TC, Munsterman KS, Speare KE, Ladd MC, Rice MM, Ezzat L, McIlroy S, Wong JCY, Baker DM, Brooks AJ, Schmitt RJ, Holbrook SJ (2020) Nitrogen identity drives differential impacts of nutrients on coral bleaching and mortality. Ecosystems 23:798-811. https://doi.org/10.1007/s10021-019-00433-2

Carlisle AB, Tickler D, Dale JJ, Ferretti F, Curnick DJ, Chapple TK, Schallert RJ, Castleton M, Block BA (2019) Estimating space use of mobile fishes in a large Marine Protected Area with methodological considerations in acoustic array design. Front Mar Sci 6:256.

https://doi.org/10.3389/fmars.2019.00256

Carr P, Votier S, Koldewey H, Godley B, Wood H, Nicoll MAC (2020) Status and phenology of breeding seabirds and a review of Important Bird and Biodiversity Areas in the British Indian Ocean Territory. BirdLife Conservation International 1-21. https://doi.org/10.1017/S0959270920000295

Chen X, Yu K, Huang X, Wang Y, Liao Z, Zhang R, Yao Q, Wang J, Wang W, Tao S, Zhang H (2019) Atmospheric nitrogen deposition increases the possibility of macroalgal dominance on remote coral reefs. J Geophy Res: Biogeosciences 124:1355-69. https://doi.org/10.1029/2019JG005074

Chong-Seng KM, Graham NAJ, Pratchett MS (2014) Bottlenecks to coral recovery in the Seychelles. Coral Reefs 33:449-461. https://doi.org/10.1007/s00338-014-1137-2

Cinner JE, Marie E, Huchery C, MacNeil MA, Graham NAJ, Mora C, McClanahan TR, Barnes ML, Kittinger JN, Hicks CC, D’Agata S, Hoey A, Gurney GG, Feary DA, Williams ID, Kulbicki M, Vigliola L, Wantiez L, Edgar G, Stuart-Smith RD, Sandin SA, Green AL, Hardt MJ, Beger M, Friedlander A, Wilson SK, Brokovich E, Brooks AJ, Cruz-Motta JJ, Booth DJ, Chabanet P, 

human impacts mediates coral reef conservation gains. Proc Nat Acad Sci USA 115:E6116E6125. https://doi.org/10.1073/pnas.1708001115

Cinner JE, Huchery C, MacNeil MA, Graham NAJ, McClanahan TR, Maina J, Maire E, Kittinger JN, Hicks CC, Mora C, Allison EH, D'Agata S, Hoey A, Feary DA, Crowder L, Williams ID, Kulbicki M, Vigliola L, Wantiez L, Edgar G, Stuart-Smith RD, Sandin SA, Green AL, Hardt MJ, Beger M, Friedlander A, Campbell SJ, Holmes KE, Wilson SK, Brokovich E, Brooks AJ, Cruz-Motta JJ, Booth DJ, Chabanet P, Gough C, Tupper M, Ferse SCA, Sumaila UR, Mouillot D (2016) Bright spots among the world's coral reefs. Nature 535:416-419. https://doi.org/10.1038/nature18607

Curnick DJ, Gollock M, Schallert R, Hussey N (2019) Evidence of dynamic resource partitioning between two sympatric reef shark species. J Fish Biol 94:680-685. https://doi.org/10.1111/jfb.13938

Curnick DJ, Collen B, Koldewey HJ, Jones KE, Kemp KM and Ferretti F (2020) Interactions between a large Marine Protected Area, pelagic tuna and associated fisheries. Front Mar Sci 7:318. https://doi.org/10.3389/fmars.2020.00318

D’Agata S, Vigliola L, Graham NAJ, Wantiez L, Parravicini V, Villéger S, Mou-Tham G, Frolla P, Friedlander AM, Kulbicki M, Mouillot D (2016) Unexpected high vulnerability of functions in wilderness areas: evidence from coral reef fishes. Proc Roy Soc Lond B 283:20160128. https://doi.org/10.1098/rspb.2016.0128

D'Angelo C, Wiedenmann J (2014) Impacts of nutrient enrichment on coral reefs: new perspectives and implications for coastal management and reef survival. Current Opinion in Environmental Sustainability 7:82-93. https://doi.org/10.1016/j.cosust.2013.11.029

Danckwerts DK, McQuaid CD, Jaeger A, McGregor GK, Dwight R, Le Corre M, Jaquemet S, (2014) Biomass consumption by breeding seabirds in the western Indian Ocean: indirect interactions with fisheries and implications for management. ICES J Mar Sci 71:2589-2598. https://doi.org/10.1093/icesjms/fsu093

Day J, Dudley N, Hockings M, Holmes G, Laffoley D, Stolton S, Wells S, Wenzel L. (eds.) (2019) Guidelines for applying the IUCN protected area management categories to marine protected areas. Second edition. Gland. Switzerland: IUCN. https://doi.org/10.25607/OBP-694

Devillers R, Pressey RL, Grech A, Kittinger JN, Edgar GJ, Ward T, Watson R (2015) Reinventing residual reserves in the sea: Are we favouring ease of establishment over need for protection? Aquatic Conservation: Marine and Freshwater Ecosystems 25:480-504. https://doi.org/10.1002/aqc. 2445

Donovan MK, Adam TC, Shantz AA, Speare KE, Munsterman KS, Rice MM, Schmitt RJ, Holbrook SJ, Burkepile DE (2020) Nitrogen pollution interacts with heat stress to increase coral bleaching across the seascape. Proc Natl Acad Sci USA 117:5351-5357. https://doi.org/10.1073/pnas.1915395117

Duarte CM, Agusti S, Barbier E, Britten GL, Castilla JC, Gattuso J-P, Fulweiler RW, Hughes TP, Knowlton N, Lovelock CE, Lotze HK, Predragovic M, Poloczanska E, Roberts C, Worm B. (2020) Rebuilding marine life. Nature 580:39-51. https://doi.org/10.1038/s41586-020-2146-7

Dunn N, Curnick D (2019) Using historical fisheries data to predict tuna distribution within the British Indian Ocean Territory Marine Protected Area, and implications for its management. Aquatic Conservation: Marine and Freshwater Ecosystems 29:2057-2070. https://doi.org/10.1002/aqc.3204

Dwyer RG, Krueck NC, Udyawer V, Heupel MR, Chapman D, Pratt HL, Garla R, Simpfendorfer CA (2020) Individual and population benefits of marine reserves for reef sharks. Curr Biol 30: 480-489. https://doi.org/10.1016/j.cub.2019.12.005

Edgar GJ, Stuart-Smith RD, Willis TJ, Kininmonth S, Baker SC, Banks S, Barrett NS, Becerro MA, Bernard ATF, Berkhout J, Buxton CD, Campbell SJ, Cooper AT, Davey M, Edgar SC, 
1062

1063

1064

1065

1066

1067

1068

1069

1070

1071

1072

1073

1074

1075

1076

1077

1078

1079

1080

1081

1082

1083

1084

Forsterra G, Galvan DE, Irigoyen AJ, Kushner DJ, Moura R, Parnell PE, Shears NT, Soler G, Strain EME, Thomson RJ (2014) Global conservation outcomes depend on marine protected areas with five key features. Nature 506:216-220. https://doi.org/10.1038/nature13022

Edis R (2004) Peak of Limuria. The story of Diego Garcia and the Chagos Archipelago. Second edition. Chagos Conservation Trust, London.

Edwards M, Beaugrand G, Hays GC, Koslow JA, Richardson AJ (2010) Multi-decadal oceanic ecological datasets and their application in marine policy and management. Trends in Ecology and Evolution 25:602-610. https://doi.org/10.1016/j.tree.2010.07.007

Enochs IC, Manzello DP (2012) Responses of cryptofaunal species richness and trophic potential to coral reef habitat degradation. Diversity 4:94-104. https://doi.org/10.3390/d4010094

Esteban N, Laloë JO, Mortimer JA, Guzman AN, Hays GC (2016) Male hatchling production in sea turtles from one of the world's largest marine protected areas, the Chagos Archipelago. Sci Rep 6:20339. https://doi.org/10.1038/srep20339

Esteban N, Unsworth RKF, Gourlay J, Hays GC (2018) The discovery of deep-water seagrass meadows in a pristine Indian Ocean wilderness revealed by tracking green turtles. Mar Poll Bull 134:99-105. https://doi.org/10.1016/j.marpolbul.2018.03.018

Ezzat L, Maguer J-F, Grover R, Ferrier-Pagès C (2016) Limited phosphorus availability is the Achilles heel of tropical reef corals in a warming ocean. Sci Rep 6:31768. https://doi.org/10.1038/srep31768

Fabricius KE (2005) Effects of terrestrial runoff on the ecology of corals and coral reefs: review and synthesis. Mar Poll Bull 50:125-146.

Ferretti F, Curnick D, Romanov EV, Block BA (2018) Shark baselines and the conservation role of remote coral reef ecosystems. Sci Adv 4:eaaq0333. https://doi.org/10.1126/sciadv.aaq0333

Genin A (2004) Bio-physical coupling in the formation of zooplankton and fish aggregations over abrupt topographies. J Mar Syst 50:3-20. https://doi.org/10.1016/j.jmarsys.2003.10.008

Giakoumi S, McGowan J, Mills M, Beger M, Bustamante RH, Charles A, Christie P, Fox M, GarciaBorboroglu P, Gelcich S, Guidetti P, Mackelworth P, Maina JM, McCook L, Micheli F, Morgan LE, Mumby PJ, Reyes LM, White A, Grorud-Colvert K, Possingham HP (2018) Revisiting "success" and "failure" of Marine Protected Areas: a conservation scientist perspective. Front Mar Sci 5:223. https://doi.org/10.3389/fmars.2018.00223

Goñi R, Hilborn R, Díaz D, Mallol S, Adlerstein S (2010) Net contribution of spillover from a marine reserve to fishery catches. Mar Ecol Prog Ser 400:233-243. https://doi.org/10.3354/meps08419

Graham NAJ, Purkis SJ, Harris A (2009) Diurnal, land-based predation on shore crabs by moray eels in the Chagos Archipelago. Coral Reefs 28:397-397. https://doi.org/10.1007/s00338-009$\underline{0488-6}$

Graham NAJ, Spalding MD, Sheppard CR (2010) Reef shark declines in remote atolls highlight the need for multi-faceted conservation action. Aquatic Conservation: marine and freshwater ecosystems 20: 543-548. https://doi.org/10.1002/aqc.1116

Graham NAJ, McClanahan TR (2013) The last call for marine wilderness? BioScience 63:397-402. https://doi.org/10.1525/bio.2013.63.5.13

Graham NAJ, Pratchett MS, McClanahan TR, Wilson SK (2013) The status of coral reef fish assemblages in the Chagos Archipelago, with implications for protected area management and climate change. In: Sheppard CRC (ed) Coral Reefs of the United Kingdom Overseas Territories. Springer, London. pp. 253-270. https://doi.org/10.1007/978-94-007-5965-7

Graham NAJ, Jennings S, MacNeil MA, Mouillot D, Wilson SK (2015) Predicting climate-driven regime shifts versus rebound potential in coral reefs. Nature 518:94-97. https://doi.org/10.1038/nature14140 
Graham NAJ, McClanahan TR, MacNeil MA, Wilson SK, Cinner JE, Huchery C, Holmes TH (2017) Human disruption of coral reef trophic structure. Curr Biol 27:231-236. https://doi.org/10.1016/j.cub.2016.10.062

Graham NAJ, Wilson SK, Carr P, Hoey AS, Jennings S, MacNeil MA (2018) Seabirds enhance coral reef productivity and functioning in the absence of invasive rats. Nature 559:250-253. https://doi.org/10.1038/s41586-018-0202-3

Green AL, Maypa AP, Almany GR, Rhodes KL, Weeks R, Abesamis RA, Gleason MG, Mumby PJ, White AT (2015) Larval dispersal and movement patterns of coral reef fishes, and implications for marine reserve network design. Biol Rev 90:1215-1247. https://doi.org/10.1111/brv.12155

Gruby RL, Gray NJ, Campbell LM, Acton L (2015) Toward a social science research agenda for large Marine Protected Areas. Cons Lett 9:153-163. https://doi.org/10.1111/conl.12194

Harris A, Wilson S, Graham NAJ, Sheppard C (2014) Scleractinian coral communities of the inner Seychelles 10 years after the 1998 mortality event. Aquatic Conservation: Marine and Freshwater Ecosystems 24:667-679. https://doi.org/10.1002/aqc.2464

Harris JL (2019) Reef manta rays, Mobula afredi, of the Chagos Archipelago: Habitat use and the effectiveness of the region's marine protected area. MRes Thesis. University of Plymouth.

Harrison HB, Williamson DH, Evans RD, Almany GR, Thorrold SR, Russ GR, Feldheim KA, van Herverden L, Planes S, Srinivasan M, Berumen NL, Jones GP (2012) Larval export from marine reserves and the recruitment benefit for fish and fisheries. Curr Biol 22:1023-1028. https://doi.org/10.1016/j.cub.2012.04.008

Hays GC, Scott R (2013) Global patterns for upper ceilings on migration distance in sea turtles and comparisons with fish, birds and mammals. Funct Ecol 27:748-756. https://doi.org/10.1111/1365-2435.12073

Hays GC, Mazaris AD, Schofield G (2014) Different male vs. female breeding periodicity helps mitigate offspring sex ratio skews in sea turtles. Front Mar Sci 1:43.

https://doi.org/10.3389/fmars.2014.00043

Hays GC, Alcoverro T, Christianen MJ, Duarte CM, Hamann M, Macreadie PI, Marsh HD, Rasheed MA, Thums M, Unsworth RK, York PH (2018) New tools to identify the location of seagrass meadows: marine grazers as habitat indicators. Front Mar Sci 5:9. https://doi.org/10.3389/fmars.2018.00009

Hays GC, Bailey H, Bograd SJ, Bowen WD, Campagna C, Carmichael RH, Casale P, Chiaradia A, Costa DP, Cuevas E, de Bruyn PJN, Dias MP, Duarte CM, Dunn DC, Dutton PH, Esteban N, Friedlaender A, Goetz KT, Godley BJ, Halpin PN, Hamann M, Hammerschlag N, Harcourt R, Harrison A-L, Hazen EL, Heupel MR, Hoyt E, Humphries NE, Kot CY, Lea JSE, Marsh H, Maxwell SM, McMahon CR, Notarbartolo di Sciara G, Palacios DM, Phillips RA, Righton D, Schofield G, Seminoff JA, Simpfendorfer CA, Sims DW, Takahashi A, Tetley MJ, Thums M, Trathan PN, Villegas-Amtmann S, Wells RS, Whiting SD, Wildermann NE, Sequeira AMM (2019) Translating marine animal tracking data into conservation policy and management. Trends in Ecology and Evolution 34:459-473. https://doi.org/10.1016/j.tree.2019.01.009

Hays GC, Cerritelli G, Esteban N, Rattray A, Luschi P (2020). Open ocean reorientation and challenges of island finding by sea turtles during long-distance migration. Curr Biol 30:32363242. https://doi.org/10.1016/j.cub.2020.05.086

Head CEI, Bonsall MB, Koldewey H, Pratchett MS, Speight M, Rogers AD (2015) High prevalence of obligate coral-dwelling decapods on dead corals in the Chagos Archipelago, central Indian Ocean. Coral Reefs 34:905-915. https://doi.org/10.1007/s00338-015-1307-X

Head CEI, Bonsall MB, Koldewey H, Jenkins TL, Pratchett MS, Rogers AD (2018) Exceptional biodiversity of the cryptofaunal decapods in the Chagos Archipelago, central Indian Ocean. Mar Poll Bull 135:636-647. https://doi.org/10.1016/j.marpolbul.2018.07.063

Head CE, Bayley DTI, Rowlands G, Roche RC, Tickler DM, Rogers AD, Koldewey H, Turner JR, Andradi-Brown DA (2019) Coral bleaching impacts from back-to-back 2015-2016 thermal 
anomalies in the remote central Indian Ocean. Coral Reefs 38:605-618. https://doi.org/10.1007/s00338-019-01821-9

Heupel M, Knip D, Simpfendorfer C, Dulvy N (2014) Sizing up the ecological role of sharks as predators. Mar Ecol Prog Ser 495:291-298. https://doi.org/10.3354/meps10597

Hosegood PJ, Nimmo-Smith WAM, Proud R, Adams K, Brierley AS (2019) Internal lee waves and baroclinic bores over a tropical seamount shark 'hot-spot'. Prog Oceanogr 172:34-50. https://doi.org/10.1016/i.pocean.2019.01.010

IOTC-SC21 (2018). Report of the 21st Session of the IOTC Scientific Committee. Seychelles, 3-7 December 2018. IOTC-2018-SC21-R[E]: $250 \mathrm{pp}$

Jacoby DMP, Ferretti F, Freeman R, Carlisle AB, Chapple TK, Curnick DJ, Dale JJ, Schallert RJ, Tickler DM, Block BA (2020) Shark movement strategies influence poaching risk and can guide enforcement decisions in a large, remote Marine Protected Area. J Appl Ecol 00:1-11. https://doi.org/10.1111/1365-2664.13654

Jacoby DMP, Freeman R (2016) Emerging network-based tools in movement ecology. Trends in Ecology and Evolution 31:301-14. https://doi.org/10.1016/j.tree.2016.01.011

Januchowski-Hartley FA, Graham NAJ, Cinner JE, Russ GR (2015) Local fishing influences coral reef fish behavior inside protected areas of the Indo-Pacific. Biol Conserv 182:8-12. https://doi.org/10.1016/j.biocon.2014.11.024

Koldewey H, Curnick D, Harding S, Harrison L, Gollock M (2010) Potential benefits to fisheries and biodiversity of the Chagos Archipelago/British Indian Ocean Territory as a no-take marine reserve. Mar Poll Bull 60:1906-1916. https://doi.org/10.1016/j.marpolbul.2010.10.002

Kroodsma D, Mayorga J, Hochberg T, Millers N, Boerder K, Ferretti F, Wilson A, Bergman B, White T, Block B, Woods P, Sullivan B, Costello C, Worm B (2018) Tracking the global footprint of fisheries. Science 359:904-908. https://doi.org/10.1126/science.aao5646

Laidre ME (2017) Ruler of the atoll: the world's largest land invertebrate. Front Ecol Environ 15:527-8. https://doi.org/10.1002/fee.1730

Lange ID, Perry CT (2019) Bleaching impacts on carbonate production in the Chagos Archipelago: influence of functional coral groups on carbonate budget trajectories. Coral Reefs 38:619-624. https://doi.org/10.1007/s00338-019-01784-X

Lange ID, Perry CT (2020) A quick, easy and non-invasive method to quantify coral growth rates using photogrammetry and 3D model comparisons. Methods Ecol Evol 00:1-13. https://doi.org/10.1111/2041-210X.13388

Lapointe BE, Brewton RA, Herren LW, Porter JW, Hu C (2019) Nitrogen enrichment, altered stoichiometry, and coral reef decline at Looe Key, Florida Keys, USA: a 3-decade study. Mar Biol 166:108. https://doi.org/10.1007/s00227-019-3538-9

Lester SE, Halpern BS, Grorud-Colvert K, Lubchenco J, Ruttenberg BI, Gaines SD, Airamé S, Warner RR (2009) Biological effects within no-take marine reserves: a global synthesis. Mar Ecol Prog Ser 384:33-46. https://doi.org/10.3354/meps08029

Letessier TB, Cox MJ, Meeuwig JJ, Boersch-Supan PH, Brierley AS (2016) Enhanced pelagic biomass around coral atolls. Mar Ecol Prog Ser 546:271-276. https://doi.org/10.3354/meps11675

Letessier TB, Mouillot D, Bouchet PJ, Vigliola L, Fernandes MC, Thompson C, Boussarie G, Turner J, Juhel JB, Maire E, Caley MJ (2019) Remote reefs and seamounts are the last refuges for marine predators across the Indo-Pacific. PLoS Biology 17:e3000366. https://doi.org/10.1371/journal.pbio.3000366

Lubchenco J, Grorud-Colvert K (2015) Making waves: The science and politics of ocean protection Science 350:382-383. https://doi.org/10.1126/science.aad5443

MacNeil MA, Graham NAJ, Cinner JE, Wilson SK, Williams ID, Maina J, Newman S, Friedlander AM, Jupiter S, Polunin NVC, McClanahan TR (2015) Recovery potential of the world's coral reef fishes. Nature 520:341-344. https://doi.org/10.1038/nature14358 
MacNeil MA, Mellin C, Matthews S, Wolff NH, McClanahan TR, Devlin M, Drovandi C, Mengersen K, Graham NAJ (2019) Water quality mediates resilience on the Great Barrier Reef. Nat Ecol Evol 3:620. https://doi.org/10.1038/s41559-019-0832-3

McClanahan TR, Graham NAJ (2015) Marine reserve recovery rates towards a baseline are slower for reef fish community life histories than biomass. Proc Roy Soc B 282:20151938. https://doi.org/10.1098/rspb.2015.1938

McClanahan TR, Graham NAJ, MacNeil MA, Cinner JE (2015) Biomass-based targets and the management of multispecies coral reef fisheries. Cons Biol 29:409-417. https://doi.org/10.1111/cobi.12430

McClanahan TR, Maina JM, Graham NAJ, Jones KR (2016) Modeling reef fish Biomass, recovery potential, and management priorities in the western Indian Ocean. PLoS ONE 11:e0154585. https://doi.org/10.1371/journal.pone.0154585

McCauley DJ, Young HS, Dunbar RB, Estes JA, Semmens BX, Micheli F (2012) Assessing the effects of large mobile predators on ecosystem connectivity. Ecol Appl 22:1711-7. https://doi.org/10.1890/11-1653.1

McCauley DJ, Pinsky ML, Palumbi SR, Estes JA, Joyce FH, Warner RR (2015) Marine defaunation: animal loss in the global ocean. Science 347:1255641. https://doi.org/10.1126/science.1255641

McCauley DJ, Gellner G, Martinez ND, Williams RJ, Sandin SA, Micheli F, Mumby PJ, McCann KS (2018) On the prevalence and dynamics of inverted trophic pyramids and otherwise topheavy communities. Ecol Lett 21:439-54. https://doi.org/10.1111/ele.12900

Mellin C, Macneil AM, Cheal AJ, Emslie MJ, Caley JM (2016) Marine protected areas increase resilience among coral reef communities. Ecol Lett 19:629-637. https://doi.org/10.1111/ele.12598

Morri C, Montefalcone M, Lasagna R, Gatti G, Rovere A, Parravicini V, Baldelli G, Colantoni P, Bianchi CN (2015) Through bleaching and tsunami: Coral reef recovery in the Maldives. Mar Poll Bull 98: 188-200. https://doi.org/10.1016/j.marpolbul.2015.06.050

Mortimer JA, Esteban N, Guzman AN, Hays GC (2020) Estimates of sea turtle nesting populations in the south-western Indian Ocean indicate the importance of the Chagos Archipelago. Oryx 54:332-343. https://doi.org/10.1017/S0030605319001108

MRAG (2015) IUU Provisional List For 2015. IOTC https://iotc.org/sites/default/files/documents/2015/04/AllEF 20150413.pdf

Murray S, Hee TT (2019) A rising tide: California's ongoing commitment to monitoring, managing and enforcing its marine protected areas. Ocean and Coastal Management 182:104920. https://doi.org/10.1016/j.ocecoaman.2019.104920

O’Leary BC, Winther-Janson M, Bainbridge JM, Aitken J, Hawkins JP, Roberts CM (2016) Effective coverage targets for ocean protection. Cons Lett 9:1-7. https://doi.org/10.1111/conl.12247

O'Leary B, Hoppit G, Townley A, Allen H, McIntyre C, Roberts CM (2020) Options for managing human threats to high seas biodiversity. Ocean \& Coastal Management. 187:105110. https://doi.org/10.1016/j.ocecoaman.2020.105110

Park J, Lee J, Seto K, Hochberg T, Wong BA, Miller NA, Takasaki K, Kubota H, Oozeki Y, Doshi S, Midzik M, Hanich Q, Sullivan B, Woods P, Kroodsma DA (2020) Illuminating dark fishing fleets in North Korea. Sci Adv 6:eabb1197. https://doi.org/10.1126/sciadv.abb1197

Perry CT, Murphy GN, Graham NA, Wilson SK, Januchowski-Hartley FA, East HK (2015) Remote coral reefs can sustain high growth potential and may match future sea-level trends. Sci Rep 5:18289. https://doi.org/10.1038/srep18289

Perry CT, Alvarez-Filip L, Graham NA, Mumby PJ, Wilson SK, Kench PS, Januchowski-Hartley F (2018) Loss of coral reef growth capacity to track future increases in sea level. Nature 558:396-400. https://doi.org/10.1038/s41586-018-0194-Z 
Plaisance L, Knowlton N, Paulay G, Meyer C (2009) Reef-associated crustacean fauna: biodiversity estimates using semi-quantitative sampling and DNA barcoding. Coral Reefs 28:977-986. https://doi.org/10.1007/s00338-009-0543-3

Preston NP, Doherty PJ (1990) Cross-shelf patterns in the community structure of coral-dwelling crustacea in the central region of the great barrier reef. I. Agile shrimps. Mar Ecol Prog Ser 66:47-61. https://doi.org/10.3354/meps066047

Queiroz N, Humphries NE, Couto A, Vedor M, da Costa I, Sequeira AMM, Mucientes G, Santos AM, Abascal FJ, Abercrombie DL, Abrantes K, Acuña-Marrero D, Afonso AS, Afonso P, Anders D, Araujo G, Arauz R, Bach P, Barnett A, Bernal D, Berumen ML, Bessudo Lion S, Bezerra NPA, Blaison AV, Block BA, Bond ME, Bonfil R, Bradford RW, Braun CD, Brooks EJ, Brooks A, Brown J, Bruce BD, Byrne ME, Campana SE, Carlisle AB, Chapman DD, Chapple TK, Chisholm J, Clarke CR, Clua EG, Cochran JEM, Crochelet EC, Dagorn L, Daly R, Devia Cortés D, Doyle TK, Drew M, Duffy CAJ, Erikson T, Espinoza E, Ferreira LC, Ferretti F, Filmalter JD, Fischer GC, Fitzpatrick R, Fontes J, Forget F, Fowler M, Francis MP, Gallagher AJ, Gennari E, Goldsworthy SD, Gollock MJ, Green JR, Gustafson JA, Guttridge TL, Guzman HM, Hammerschlag N, Harman L, Hazin FHZ, Heard M, Hearn AR, Holdsworth JC, Holmes BJ, Howey LA, Hoyos M, Hueter RE, Hussey NE, Huveneers C, Irion DT, Jacoby DMP, Jewell OJD, Johnson R, Jordan LKB, Jorgensen SJ, Joyce W, Keating CA, Ketchum JT, Klimley AP, Kock AA, Koen P, Ladino F, Lana FO, Lea JSE, Llewellyn F, Lyon WS, MacDonnell A, Macena BCL, Marshall H, McAllister JD, McAuley R, Meÿer MA, Morris JJ, Nelson ER, Papastamatiou YP, Patterson TA, Peñaherrera-Palma C, Pepperell JG, Pierce SJ, Poisson F, Quintero LM, Richardson AJ, Rogers PJ, Rohner CA, Rowat DRL, Samoilys M, Semmens JM, Sheaves M, Shillinger G, Shivji M, Singh S, Skomal GB, Smale MJ, Snyders LB, Soler G, Soria M, Stehfest KM, Stevens JD, Thorrold SR, Tolotti MT, Towner A, Travassos P, Tyminski JP, Vandeperre F, Vaudo JJ, Watanabe YY, Weber SB, Wetherbee BM, White TD, Williams S, Zárate PM, Harcourt R, Hays GC, Meekan MG, Thums M, Irigoien X, Eguiluz VM, Duarte CM, Sousa LL, Simpson SJ, Southall EJ, Sims DW (2019) Global spatial risk assessment of sharks under the footprint of fisheries. Nature 572:461-466. https://doi.org/10.1038/s41586-019-1444-4

Richardson AJ, Downes KJ, Nolan ET, Brickle P, Brown J, Weber N, Weber SB (2018) Residency and reproductive status of yellowfin tuna in a proposed large-scale pelagic marine protected area. Aquat Conserv Mar Freshw Ecosyst 28:1308-16 https://doi.org/10.1002/aqc.2936

Roberts CM, O'Leary BC, McCauley DJ, Cury PM, Duarte CM, Lubchenco J, Pauly D, SáenzArroyo A, Sumaila UR, Wilson RW, Worm B, Castilla JC (2017) Marine reserves can mitigate and promote adaptation to climate change. Proc Natl Acad Sci USA 114:6167-6175.

https://doi.org/10.1073/pnas.1701262114

Roche RC, Pratchett MS, Carr P, Turner JR, Wagner D, Head C, Sheppard CRC (2015) Localized outbreaks of Acanthaster planci at an isolated and unpopulated reef atoll in the Chagos Archipelago. Mar Biol 162:1695-1704. https://doi.org/10.1007/s00227-015-2708-7

Sala E, Lubchenco J, Grorud-Colvert K, Novelli C, Roberts C, Sumaila UR (2018) Assessing real progress towards effective ocean protection. Marine Policy 91:11-13. https://doi.org/10.1016/j.marpol.2018.02.004

Savage C (2019) Seabird nutrients are assimilated by corals and enhance coral growth rates. Sci Rep 9:1-10. https://doi.org/10.1038/s41598-019-41030-6

Sequeira AMM, Hays GC, Sims DW, Eguíluz VM, Rodriguez J, Heupel M, Harcourt R, Callich H, Queiroz N, Costa DP, Fernández-Gracia J, Ferreira LC, Goldsworthy SD, Hindell M, Lea MA, Meekan M, Pagano A, Shaffer SA, Reisser J, Thums M, Weise M, Duarte CM (2019) Overhauling ocean spatial planning to improve marine megafauna conservation Front Mar Sci. 6:639. https://doi.org/10.3389/fmars.2019.00639 
1283

1284

1285

1286

1287

1288

1289

1290

1291

1292

1293

1294

1295

1296

1297

1298

1299

1300

1301

1302

1303

1304

1305

1306

1307

1308

1309

1310

1311

1312

1313

1314

1315

1316

1317

1318

1319

1320

1321

1322

1323

1324

1325

1326

1327

1328

1329

1330

1331

Schofield G, Esteban N, Katselidis KA, Hays GC (2019) Drones for research on sea turtles and other marine vertebrates - a review. Biol Cons 238:108214. https://doi.org/10.1016/j.biocon.2019.108214

Shantz AA, Burkepile DE (2014) Context-dependent effects of nutrient loading on the coral-algal mutualism. Ecology 95:1995-2005.

Sheehan E, Hosegood P, Game C, Attrill M, Tickler D, Wootton M, Johns D, Meeuwig J (2019) The effect of deep oceanic flushing on water properties and ecosystem functioning within atolls in the British Indian Ocean Territory. Front. Mar. Sci 6:512. https://10.3389/fmars.2019.00512

Sheppard CRC (1980) Coral cover, zonation and diversity on reef slopes of Chagos Atolls, and population structures of the major species. Mar Ecol Prog Ser 2:193-205. https://doi.org/10.3354/meps002193

Sheppard CR, Ateweberhan M, Bowen BW, Carr P, Chen CA, Clubbe C, Craig MT, Ebinghaus R, Eble J, Fitzsimmons N, Gaither MR (2012) Reefs and islands of the Chagos Archipelago, Indian Ocean: why it is the world's largest no-take marine protected area. Aquat Conserv Mar Freshw Ecosyst 22:232-61. https://doi.org/10.1002/aqc.1248

Sheppard CRC, Sheppard A, Mogg A, Bayley D, Dempsey AC, Roche, R, Turner J, Purkis S (2017) Coral bleaching and mortality in the Chagos Archipelago. Atoll Res Bull 613:1-26.

https://doi.org/10.5479/si.0077-5630.613

Sheppard CRC, Sheppard ALS (2019) British Indian Ocean Territory (Chagos Archipelago). In: CRC, Sheppard (Ed.), 2019. World Seas: An Environmental Assessment. vol. 3. Academic Press, pp. 237-252. https://doi.org/10.1016/b978-0-08-100853-9.00015-4

Sheppard C, Sheppard A, Fenner D (2020) Coral mass mortalities in the Chagos Archipelago over 40 years: regional species and assemblage extinctions and indications of positive feedbacks. Mar Poll Bull 154:111075. https://doi.org/10.1016/j.marpolbul.2020.111075

Stella JS, Pratchett MS, Hutchings PA, Jones GP (2011) Coral-associated in- vertebrates: diversity, ecological importance and vulnerability to disturbance. Oceanogr Mar Biol 49:43-104. https://doi.org/10.1201/b11009-3

Stewart JD, Jaine FRA, Armstrong AJ, Armstrong AO, Bennett MB, Burgess KB, Couturier LIE, Croll DA, Cronin MR, Deakos MH, Dudgeon CL, Fernando D, Froman N, Germanov ES, Hall MA, Hinojosa-Alvarez S, Hosegood JE, Kashiwagi T, Laglbauer BJL, Lezama-Ochoa N, Marshall AD, McGregor F, Notarbartolo di Sciara G, Palacios MD, Peel LR, Richardson AJ, Rubin RD, Townsend KA, Venables SK, Stevens GMW (2018) Research priorities to support effective manta and devil ray conservation. Front Mar Sci 5:314. https://doi.org/10.3389/fmars.2018.00314

Sumaila R, Lam V, Miller D, Teh L, Watson R, Zeller D, Cheung WWL, Côté IM, Rogers AD, Roberts C, Sala E, Pauly D (2015) Winners and losers in a world where the high seas is closed to fishing. Sci Rep 5:8481. https://doi.org/10.1038/srep08481

Taylor BM, Choat JH, DeMartini EE, Hoey AS, Marshell A, Priest MA, Rhodes KL, Meekan MG (2019) Demographic plasticity facilitates ecological and economic resilience in a commercially important reef fish. J Anim Ecol 88:1888-1900. https://doi.org/10.1111/1365-2656.13095

Taylor BM, Benkwitt CE, Choat H, Clements KD, Graham NA, Meekan MG. (2020a) Synchronous biological feedbacks in parrotfishes associated with pantropical coral bleaching. Glob Chang Biol 26:1285-1294. https://doi.org/10.1111/gcb.14909

Taylor BM, Chinkin M, and Meekan MG (2020b) Teleconnections reveal that drivers of inter-annual growth can vary from local to ocean basins in tropical snappers. Coral Reefs 39:397-407. https://doi.org/10.1007/s00338-020-01903-z

Tickler DM, Carlisle AB, Chapple TK, Curnick DJ, Dale JJ, Schallert RJ, Block BA (2020) Potential detection of illegal fishing by passive acoustic telemetry. Animal Biotelemetry 7:1. https://doi.org/10.1186/s40317-019-0163-9 
1332

1333

1334

1335

1336

1337

1338

1339

1340

1341

1342

1343

1344

1345

1346

1347

1348

1349

1350

1351

1352

1353

1354

1355

1356

1357

1358

1359

1360

1361

1362

1363

1364

1365

1366

1367

1368

1369

1370

1371

1372

1373

1374

Tickler DM, Letessier TB, Koldewey HJ, Meeuwig JJ (2017) Drivers of abundance and spatial distribution of reef-associated sharks in an isolated atoll reef system. PloS One 12: e0177374. https://doi.org/10.1371/journal.pone.0177374

Toth LT, van Woesik R, Murdoch TJT, Smith SR, Ogden JC, Precht WF, Aronson RB (2014) Do no-take reserves benefit Florida's corals? 14 years of change and stasis in the Florida Keys National Marine Sanctuary. Coral Reefs 33:565-577. https://doi.org/10.1007/s00338-014$1158-\mathrm{X}$

Turner JA, Babcock RC, Hovey R, Kendrick GA (2017) Deep thinking: a systematic review of mesophotic coral ecosystems. ICES J Mar Sci 74:2309-2320. https://doi.org/10.1093/icesjms/fsx085

United Nations (2019). Meetings coverage and press releases. https://www.un.org/press/en/2019/ga12146.doc.htm

van Hooidonk R, Maynard J, Tamelander J, Gove J, Ahmadia G, Raymundo L, Williams G, Heron SF, Planes S (2016) Local-scale projections of coral reef futures and implications of the Paris Agreement. Sci Rep 6:39666. https://doi.org/10.1038/srep39666

Wakefield ED, Bodey TW, Bearhop S, Blackburn J, Colhoun K, Davies R, Dwyer RG, Green JA, Grémillet D, Jackson AL, Jessopp MJ, Kane A, Langston RHW, Lescroël A, Murray S, Nuz M Le, Patrick SC, Péron C, Soanes LM, Wanless S, Votier SC, Hamer KC (2013) Space partitioning without territoriality in gannets. Science 341:68-70. https://doi.org/10.1126/science.1236077

Weimerskirch H, Collet J, Corbeau A, Pajot A, Hoarau F, Marteau C, Filippi D, Patrick SC (2019) Ocean sentinel albatrosses locate illegal vessels and provide the first estimate of the extent of nondeclared fishing. Proc Natl Acad Sci USA 117:3006-3014. https://doi.org/10.1073/pnas.1915499117

Wenban-Smith N, Carter M (2017) Chagos: A History. Chagos Conservation Trust, London.

Wiedenmann J, D'Angelo C, Smith EG, Hunt AN, Legiret F-E, Postle AD, Achterberg EP (2013) Nutrient enrichment can increase the susceptibility of reef corals to bleaching. Nat Clim Change 3:160-164. https://doi.org/10.1038/nclimate1661

Williams JJ, Papastamatiou YP, Caselle JE, Bradley D, Jacoby DMP (2018a) Mobile marine predators: An understudied source of nutrients to coral reefs in an unfished atoll. Proc Roy Soc Lond B 285:20172456. https://doi.org/10.1098/rspb.2017.2456

Williams GJ, Roche RC, Turner JR (2018b) First record of coralline fungal disease (CFD) in the Indian Ocean. Coral Reefs 37:1243. https://doi.org/10.1007/s00338-018-1704-z

Woodley S, Baillie JE, Dudley N, Hockings M, Kingston N, Laffoley D, Locke H, Lubchenco J, MacKinnon K, Meliane I, Sala E (2019) A bold successor to Aichi Target 11. Science 365:649-650. https://doi.org/10.1126/science.aay2768

Woodson CB, Schramski JR, Joye SB (2018) A unifying theory for top-heavy ecosystem structure in the ocean. Nat Commun 9:1-8. https://doi.org/10.1038/s41467-017-02450-y

Wooldridge SA, Done TJ (2009) Improved water quality can ameliorate effects of climate change on corals. Ecol Appl 19:1492-1499. https://doi.org/10.1890/08-0963.1

Wright J (2016) Analysing the relationship between senescing Acropora tables and disease prevalence in the absence of anthropogenic pressures. Master of Marine Biology Thesis. School of Ocean Sciences, Bangor University, UK. 31 pp. 